\title{
The Liber ex lege Moysi: Notes and Text ${ }^{*}$
}

\author{
by Sven Meeder
}

The so-called Liber ex lege Moysi (hereafter Liber) is an important witness to the significance of biblical law in the early medieval Irish Church, and the Irish jurists' approach to, and active dialogue with, the legal material of the Old Testament. It has been unjustly neglected by scholarship and a critical edition of the text has never been published. ${ }^{1}$ This may be due to the fact that the Liber, a short text made up out of selected prescriptions taken from the Bible books Exodus, Leviticus, Numbers, and Deuteronomy, consists merely of biblical texts, and as such seems to present the historian with little new material. The work, however, is potentially very illuminating for the study of the Irish understanding of the Bible, as well as the reception of Irish biblical scholarship on the continent.

Early medieval Irish society was deeply influenced by the Bible and in particular by the Old Testament. The significance of this influence is evident in the large number of Old-Testament quotations in non-biblical works, notably in texts of ecclesiastical law (in particular the Collectio canonum Hibernensis) as well as secular law. These works often bespeak a literal and normative interpretation of Old-Testamental law. Engaging in a dialogue with biblical principles, the Irish law texts display deliberate efforts to model important aspects of Irish culture on the Old Testament, especially on the prescriptions found in the Pentateuch. Priests in Ireland, for instance, were

* I am very grateful to Prof. Rosamond McKitterick, Dr. Martin Brett, Dr. Roy Flechner, and the anonymous JMLat reader for their critical proofreading of earlier versions of this paper and their helpful advice.

${ }^{1}$ Only two articles deal with the Liber in detail: Paul Fournier, "Le Liber ex lege Moysi et les tendances bibliques du droit canonique Irlandais," Revue Celtique 30 (1909), pp. 221-34; Raymund Kottje, "Der Liber ex lege Moysis," in Irland und die Christenheit / Ireland and Christendom. Bibelstudien und Mission / The Bible and the Missions, ed. P. Ní Chatháin and M. Richter (Stuttgart, 1987), pp. 59-69. See also Leslie Hardinge, The Celtic Church in Britain (London, 1972), esp. pp. 209-16. 
repeatedly styled as Old Testament Levites, and Irish monasteries and churches assumed the role of biblical cities of refuge. ${ }^{2}$

The Liber attests to a literal and historical interpretation of the Bible, presenting the biblical rules, stripped from their biblical context, as a collection of practical laws that were to be taken literally and seriously in their own right. The selection process reveals much about the specifically legal interest of the author and the textual strategy employed to shape the Old-Testamental directives into a practical collection of divine law. Significant are not only the Bible verses featured, but also the ones omitted by the author, or taken up partly or in a truncated form. There are, furthermore, indications that in some instances the biblical text was actively adapted to fit the format of the Liber. In addition, since no contemporary Irish manuscript copies of the Pentateuch survive, the Liber with its frequently idiosyncratic readings of the Bible text, contributes to our understanding of the Bible version(s) used in Ireland. The textual history of the Liber is furthermore of interest to students of the reception of Irish scholarship on the Continent. In three of the surviving four continental manuscript copies, the Liber is annotated (sometimes copiously) with explicatory glosses in Latin, Irish or Old Breton. These glosses offer unique insights into the Irish perception of, and the continental response to, this use of Mosaic law.

\section{The text}

Without rubrics or headings, the Liber presents the directives taken from 297 Bible verses of the Pentateuch in the form of legal decrees. The book of Numbers provides only six verses, whereas the three other books - Exodus, Leviticus, and Deuteronomy - supply almost equal portions of the text. In some instances an extract consists of only part of a verse, at others it consists of a complete verse, or several verses. Long connected passages are especially taken from Exodus and Leviticus, while most of the extracts from Deuteronomy consist of single verses or a small number of linked verses.

In principle, the order of the verses in the Liber is that of the Bible. Thematically linked passages in different Bible books are, as a result, not grouped together, but feature among the other verses from the respective Bible books. The arrangement according to "thematischen Gesichtspunkten," recognized by Raymund Kottje, is therefore the arrangement as it

\footnotetext{
${ }^{2}$ See Liam Breatnach, Donnchadh Ó Corráin and Aidan Breen, "The Laws of the Irish," Peritia 3 (1984), pp. 382-438, at pp. 394-400.
} 
is found in the Bible, not one introduced by the composer of the Liber. ${ }^{3}$ In some instances, however, the compiler seems to have omitted certain passages to avoid repeating similar ordinances, or for brevity. ${ }^{4}$

The selection in the Liber contains material from only a fraction of the total number of verses in the four books. The careful selection of texts and the rigorous deletion of much of the biblical context of the legal directives demonstrate that the aim of the Liber was not so much to supply jurists and scholars with biblical references and precedents to furnish their legal texts, but rather to produce a law-book in its own right. Raymund Kottje explained how the ordinances included in the Liber can all be believed to have held some normative meaning for the time of the compiler. ${ }^{5}$ The compiler made great efforts to ensure that references to the Old Testamental context of the ordinances were left out of the text, so emphasizing their universal significance. The directive on the inheritance of a man without male heirs in Numbers 27.7-11 is a case in point. In the Bible, Moses's judgement on the matter is prompted by the pleadings of Salphaad's daughters, whose father died without sons and who demanded an inheritance (Numbers 27.1-6). This context is cited in detail by Irish canon lawyers in the early eighth-century Collectio canonum Hibernensis. ${ }^{6}$ The Liber, however, lacks any mention of the context of the rulings, presenting only Moses's subsequent directives as laws. The purpose of the inclusion in the Liber of the ruling given by Moses to the daughters of Salphaad seems not to have been to provide a story to serve as precedent justifying Old Irish legal rules or customs, but to distil a legal rule out of it. ${ }^{7}$

As a rule, the historical passages of the Bible books, as well as the theological background, are left out of the Liber. This is done so consistently that it often results in parts of a single verse being omitted. The occasional references to biblical persons are mostly restricted to Moses and, sporadically, to (the sons of) Israel, which may be interpreted rather loosely

${ }^{3}$ Kottje discerns 69 thematic sections, Kottje, "Liber ex lege Moysis," p. 60. Leslie Hardinge divides the text in 35 sections, Celtic Church, p. 210.

${ }^{4}$ For instance Leviticus 12.6, see Kottje, "Liber ex lege Moysis," p. 61.

${ }^{5}$ Ibid.

${ }^{6}$ Collectio canonum Hibernensis, ed. Hermann Wasserschleben, Die irische Kanonensammlung (Leipzig, 1885) 32.19; see also Donnchadh Ó Corráin, "Irish Law and Canon Law," in Irland und Europa / Ireland and Europe. Die Kirche im Frühmittelalter / The Early Church, ed. P. Ní Chatháin and M. Richter (Stuttgart, 1984), pp. 157-66, at 160-61.

${ }^{7}$ Compare Pádraig P. Ó Néill, Biblical Study and Mediaeval Gaelic History, Quiggin Pamphlets on the Sources of Mediaeval Gaelic History 6 (Cambridge, 2003), p. 26; and Ó Corráin, "Irish Law and Canon Law," pp. 157-61. 
to refer to the faithful. In the selection process there was a clear awareness of the fact that some of the precepts reflected pre-Christian times and were not relevant for the time and place of composition. Verses concerned with ancient Jewish ceremonies and rituals are left out. This may in fact bespeak a sense of history on the part of the compiler. The rigorous omissions of historical allusions could actually testify to a consciousness of the fact that the Old Testament is a work that provides an account of the history of the Jewish people in Mosaic times and rules specific for that time and place, as well as rules given to and by Moses with universal value. Indeed, the laws of Moses are presented not as exempla, but as practical laws as in any other law book.

These editorial efforts have resulted in a text, which in form is close to early medieval law tracts, synodal constitutions, or, as Kottje pointed out, Irish penitential texts, with individual and short precepts. ${ }^{8}$ The character of the contents of the Liber, however, is different from the penitentials. While certain verses are less legalistic and more moral, such as the prohibition to eat unclean food and the repeated commandment not to believe in other gods, the great majority of the ordinances are strictly juridical. Personal matters, invoking the love or fear of God, are largely absent and verses which command people to have a certain opinion about morals are frequently omitted. An example is found in the inclusion of the first part of Leviticus 7.26, reminding people not to bring any thing of the idol in one's house, but the subsequent absence of the second part of the verse in the Liber, which states that the people should "detest it as dung" and "utterly abhor it."

The compiler's main interest lay in practical law, involving one's duties and responsibilities towards fellow men, and much less in moral guidelines. This emphasis on the juridical nature of the Liber is established in one of the first verses. Exodus 20.6 describes how God shows mercy unto thousands that love him and keep his commandments. The Liber, in the version of Orléans MS 221, however, has the thousands "love my commandments," possibly signalling at an early stage that the love for God is not the topic of this book, but rather the laws. The strictly juridical emphasis is also reflected in the non-Vulgate reading of the next verse, where the Liber reading warns people not to take God's name in vain "in an oath" (iuramento), thereby introducing this commandment into a clear legal context and alluding to judicial proceedings. The Liber thus gives prominence to the responsibilities towards fellow men and, consequently, to punishments that were to be

\footnotetext{
${ }^{8}$ Kottje, "Liber ex lege Moysis," p. 61.
} 
exacted by society. Threats of God's anger are duly excluded from the biblical passages, such as in Deuteronomy 18.10-12 (found only in Corpus Christi College MS 279, (W)), referring to wizards and soothsayers, which omits the sub-clause warning that for these abominations God will destroy them, or in the absence of the repeated foreshadowing of offenders being "vomited out of their land" (Leviticus 18.25, 28; 20.22). Similarly, God's promises of blessing and assistance to those who keep his commandments are absent in the Liber (see for instance the exclusion of verses from Leviticus 26, and the absence of Deuteronomy 6.1-3, 10-12, 17-25), even though similar promises are alluded to in other Irish religious traditions. ${ }^{9}$

This indicates that the Liber is not a penitential and that it does not provide details on the expiation of sins through penance. A case in point is the passage from Leviticus 6.2-6 taken up in the Liber, which deals with fraud against one's neighbour. Although it ends with the offender having to offer a ram without blemish for his sin, the Liber omits the following words (Leviticus 6.7) where the priest "shall pray for him before the Lord, and he shall have forgiveness for every thing in doing of which he has sinned."

In addition to the partial exclusion of biblical verses, certain peculiar non-Vulgate readings affect the context and meaning of the biblical decrees in the Liber. Most non-Vulgate readings take the form of Vulgate-variants, where the meaning of the Bible verse is not, or only slightly, affected, such as minor omissions of (personal) pronouns and other words, changed word order (eg. est mortuus for mortuus est in Exodus 21.34), the use of interchangeable words (eg. cuncta for omnia in Exodus 20.11, or eius for illius in Exodus 21.21) or the use of different cases (eg. filios for filiis in Exodus 20.5). In some cases, however, the deviation has obvious implications for the interpretation of the biblical decrees. It is often unclear whether the non-Vulgate passages are the result of conscious editing by the compiler of the Liber or whether these wordings were already present in the version of the Bible used by the author. Some of the variants may also be the result of a copyist entering interlinear glosses within the text. Notwithstanding these observations, the non-Vulgate readings influenced the character of the Liber and they may shed some additional light on the context in which Irish scholars viewed the biblical passages. The unique incorporation of the word iuramento in Exodus 12.7 has already been discussed above. The Liber furthermore varies from the Vulgate in its

\footnotetext{
${ }^{9}$ For instance in a prayer in the Stowe Missal; see Sven Meeder, "The Early Irish Stowe Missal's Destination and Function," Early Medieval Europe 13 (2005), 179-94, at pp. 18687.
} 
reading of Leviticus 12.5 on the number of days of impurity after childbirth (46 instead of the Vulgate's 66 - see below). Similarly, the number of days in the Liber's rendering of Exodus 22.30 are different from the Vulgate. Describing the practice of firstlings for cattle and sheep, the verse states that a young calf or lamb is to stay six days with its mother and should be given to the Church on the seventh day, whereas in the Vulgate this is seven days and the eighth day respectively. Whether or not a conscious alteration lay behind this difference is unclear.

A variant reading of Exodus 21.16 certainly altered the verse's meaning: The Vulgate version describes how someone who steals a man, and sells him, when convicted should die ("Qui furatus fuerit hominem, et uendiderit eum, conuictus: noxae mortae moriatur"). The oldest manuscript witness of the Liber (Orléans 221 (A)) has fraudatus ("defrauded") for furatus, thereby changing the nature of the crime. It is clear that the change is deliberate, for the following clause, et uendiderit eum, being now inappropriate in this context, has been removed. ${ }^{10}$ Other variations to the Vulgate version of biblical verses are Exodus 22.6 ("et incenderit aream aut segetem aut uineas aut campum" added), 22.9 (dampnum for duplum, domino for proximo); Leviticus 11.36 (idem inmundorum animalium added), 12.6 (inmaculatum for anniculum), 17.5 (per ignorantiam added), 18.17 (sororis for uxoris), 19.17 (placide for publice), 19.19 (coloribus added), 19.20 (nobilis for nubilis), 20.9 (uel in patientia/penitentia added), 20.21 (filiis morientur for liberis erunt), 27.3 ( $X L$ for $L X), 27.5(X V$ for $X)$. In other cases the significance of biblical verses is altered by a change in order. The first four verses of Exodus 22 are reproduced in the order 22.1, 22.3 (fragment), 22.4, 22.2, 22.3 (fragment). Leviticus 11.33, 35-6 in the Liber follow Leviticus 7.26-7, as a result of which they appear be concerned with blood rather than unclean animals. Furthermore, the inclusion of verses Deuteronomy 18.10 12 in $\mathbf{W}$ in between Deuteronomy 19.13 and 19.15-16 brings the precepts on soothsayers and wizards into the context of hearing witnesses and giving witness in legal proceedings. Most of these idiosyncrasies have a distinct influence on the meaning of the biblical decree and they seem to be the products of deliberate textual reworkings aimed to provide the Liber with the features of a very practical and strictly juridical collection of biblical law.

\footnotetext{
${ }^{10}$ Manuscript Cambridge, Corpus Christi 279 (W) has fradus; Paris 3182 (B) has the Vulgate reading. This element is lost in Cotton Otho E.XIII (O).
} 


\section{Origin and date}

The Irish origin of the Liber is indicated by much circumstantial evidence. The text survives in four manuscripts that all contain collections of insular, and in particular Irish works. All manuscripts, furthermore, originate from or are closely associated with Brittany, a region that played an important role in the preservation of insular texts and where Irish (and British) religious practices were adopted with vigour. In addition, all four manuscript witnesses to the Liber have certain Irish symptoms, including glosses in OldIrish.

The contents and form of the text also appear to point to Ireland. The importance accorded to the Old Testament in the Irish Church and its influence on the organisation of religious life is widely recognized and evidenced by many Irish works. ${ }^{11}$ Clare Stancliffe recently demonstrated how a rather different concept of the legal authority of the Bible was one of the underlying reasons for Columbanus's problems with the Gallic bishops. ${ }^{12}$ The Irish attitude to the Bible as constituting a "lex" for Christians is evident not only in the penitentials and the Hibernensis, but goes as far back as St. Patrick. ${ }^{13}$ The Liber is an impressive witness to the Irish predilection for according juridical value to Biblical prescriptions. ${ }^{14}$ In Kottje's opinion, a work displaying such legalistic use of the Old Testament can really only originate from Ireland. ${ }^{15}$

But most importantly, the Liber can be associated with other works of Irish origin, such as the Hibernensis and some penitentials. Bible verses from Exodus, Leviticus and Deuteronomy, included in the Liber, feature in the penitential of Cummean, the so-called "Bigotian penitential," the

\footnotetext{
${ }^{11}$ See Raymund Kottje, Studien zum Einflu $\beta$ des Alten Testamentes auf Recht und Liturgie des frühen Mittelalters (6.-8. Jahrhundert), Bonner Historische Forschungen 23 (Bonn, 1970), pp. 11, 15-43, 108; Donnchadh Ó Corráin, "Irish Vernacular Law and the Old Testament," in Irland und die Christenheit / Ireland and Christendom. Bibelstudien und Mission / The Bible and the Missions, ed. P. Ní Chatháin and M. Richter (Stuttgart, 1987), pp. 284-307; Maurice Sheehy, "The Bible and the Collectio Canonum Hibernensis," in Irland und die Christenheit, ed. Ní Chatháin and Richter, pp. 277-83.

${ }^{12}$ Clare Stancliffe, "Columbanus and the Gallic Bishops," in Auctoritas: Mélanges offerts au professeur Olivier Guillot, Cultures et Civilisations Médiévales 33, ed. G. Constable and M. Rouche (Paris, 2006), pp. 205-15.

${ }^{13}$ Patrick, Epistola, c. 9, ed. Ludwig Bieler, Libri epistolarum sancti Patricii episcopi (Dublin, 1952, repr. 1993); see Thomas Charles-Edwards, Early Christian Ireland (Cambridge, 2000), pp. 232-33.

${ }^{14}$ Demonstrated first by Fournier, "Liber ex lege Moysi."

${ }^{15}$ Kottje, "Liber ex lege Moysis," p. 61.
} 
Canones Hibernenses, and the Canones Adamnani. ${ }^{16}$ The particularly strong relation between the Hibernensis and the Liber is demonstrated by the fact that both texts share certain peculiar non-Vulgate readings of Bible verses. Both the Liber as well as the Hibernensis, in their rendering of Leviticus $12: 5$, state that after the birth of a daughter a women is unclean for 46 days (where the Vulgate has 66 - see above), a variant that is not found in other earlier or contemporary texts. ${ }^{17}$

Kottje remarked that this variant reading is probably the result of a copying error $(X L$ for $L X)$ that made its way into copies of the Bible used for both the compilation of the Hibernensis and the Liber, but since the topic saw some debate at the time, judging from the correspondence of Gregory the Great and Augustine of Canterbury, and the penitential of Theodore, there is also a possibility that the reading reflects a conscious alteration. ${ }^{18}$ The same fundamental debate can be the cause of the unconventional reading of Leviticus 12.4 which features in some copies of the Liber and the Hibernensis. Where the Vulgate states that after the birth of a son, a woman shall remain in the blood of her purification for thirty-three days (half of sixty-six), the Hibernensis has a number of thirty-six $(X X X V I)$, as do two copies of the Liber. ${ }^{19}$ On the other hand, this might again reflect a scribal error.

Other biblical citations in the Liber similarly share a variant reading with the Hibernensis, including Leviticus 5.1, where both texts repeat the word testis in the second sub-clause of the verse ("... aut concius testis est"), a reading that is not attested anywhere else. ${ }^{20}$ Both texts also have merces for opus in their reading of Leviticus 19.13 ("non demoretur merces mercennarii ..."). ${ }^{21}$

\footnotetext{
${ }^{16}$ See the table below and Ludwig Bieler, The Irish Penitentials, Scriptores Latini Hiberniae 5 (Dublin, 1963), p. 288.

${ }^{17}$ Collectio canonum Hibernensis, 46.11. The extant manuscript copies of the Penitential of Cummean follow the Vulgate reading of Lev. 12.5; Paenitentiale Cummeani 2.31, ed. and trans. Bieler, Irish Penitentials, pp. 108-35, at 116.

${ }^{18}$ Kottje, "Liber ex lege Moysis," p. 65; for a discussion of the debate in the Liber responsionum of Gregory the Great and in the Penitential of Theodore of Tarsus, see Rob Meens, "Ritual Purity and the Influence of Gregory the Great in the Early Middle Ages," in Unity and Diversity in the Church, Studies in Church History 32, ed. R.N. Swanson (Oxford, 1996), pp. 31-43.

${ }^{19}$ Collectio canonum Hibernensis, 46.11; Liber ex lege Moysi, s. Lev. 12.4 (MSS B, W).

${ }^{20}$ Collectio canonum Hibernensis, 35.10; Liber ex lege Moysi, s. Lev. 5.1 (MSS A, B, O).

${ }^{21}$ Collectio canonum Hibernensis, 33.5; Liber ex lege Moysi, s. Lev. 19.13.
} 
The date of the Liber's composition remains unknown. The oldest manuscript dates from the first half of the ninth century, providing the ultimate terminus post quem non. The association between the Hibernensis and the Liber led Kottje to believe that the latter probably stands close to the Hibernensis in date and origin, which he believed to be around 700 at Iona. ${ }^{22}$ However, we do not know how many different copies, or recensions, of the Pentateuch circulated in Ireland at any time, so we can say very little with any certainty about the closeness of the association between the two texts on the basis of biblical readings. Another indication of the Liber's date was found by Kottje in the inclusion of Leviticus 19.27: "Nec in rotundum adtendebitis comam nec radatis barbam," "Neither shall you cut your hair roundwise: nor shave your beard." This verse may have been included to refer to the Irish manner of tonsure and as such it could be used as a marker for a date prior to the settlement of the disputes over Irish ecclesiastical customs, such as the calculation of Easter and, in particular, the Irish tonsure. A place of composition at a centre where opposition against the Roman practices was particularly present or enduring, for instance one of the centres identified in Pope-Elect John's letter of 640 to the bishops and abbots of northern Ireland regarding the Easter controversy and the Pelagian heresy, is equally imaginable. ${ }^{23}$ This prescription, therefore, could indicate a date for the Liber before the end of the seventh century, or, in Iona's case, before 716 or 718 . It is uncertain, however, if this is the correct assessment of the presence of this biblical verse, since its inclusion was apparently not offensive enough for later continental audiences to prevent its copying in later centuries. Only the oldest manuscript witness (Orléans 221) could theoretically have been produced before the monks of Landévennec abandoned the "Irish" customs and tonsure and welcomed the rule of St. Benedict in $818 .^{24}$ There is, furthermore, as far as I know no precedent for the use of this Bible verse in relation to the question of the insular tonsure,

${ }^{22}$ Kottje, "Liber ex lege Moysis," pp. 66-65.

${ }^{23}$ Kottje, "Liber ex lege Moysis," p. 66; John's letter is cited in Bede, Historia ecclesiastica, 2.19; on the charge of Pelagianism, see Dáibhí Ó Cróinín, “"New Heresy for Old': Pelagianism in Ireland and the Papal letter of 640," Speculum 60 (1985), pp. 505-16; and a response to his conclusion in Michael W. Herren and Shirley Ann Brown, Christ in Celtic Christianity: Britain and Ireland from the Fifth to the Tenth Century, Studies in Celtic History 20 (Woodbridge, 2002), p. 88.

${ }^{24}$ Wrdisten, Vita S. Winwaloei primi abbatis landevenecensis auctore Wurdestino, 2.12 13, ed. C. de Smedt, Analecta Bollandiana 7 (1888), pp. 167-264, at 226-27; see Julia M.H. Smith, Province and Empire. Brittany and the Carolingians, Cambridge Studies in Medieval Life and Thought 18 (Cambridge, 1992), p. 72. 
and one wonders why the selective compilers, if they wanted to refer to the insular tonsure, did not omit the part about the beard.

Leslie Hardinge draws attention to a phrase in the so-called Tripartite life of St. Patrick, in which the saint is said to have left "a book of the Law and the books of the Gospel" at every church he founded. He remarks that the Liber best corresponds to the description of the "book of the Law," and, consequently, he seems to date the text to the times of St. Patrick. ${ }^{25}$ Hardinge's conclusion is based on his appraisal of the role of the text in the early Irish Church as "paramount," not only reflecting the juridical use of the Old Testament, but actually acting as the source of decrees for canon, as well as vernacular law. ${ }^{26}$ There is little evidence, however, for Hardinge's supposition and his early dating of the Liber, since it was demonstrably not the only contemporary witness to the books of the Pentateuch available on the British Isles. Many Pentateuch verses missing in the Liber, for example, are cited in other Irish texts, such as the penitentials and the Hibernensis. An origin before the end of the seventh century, contemporary with the height of Old Testament study in Ireland and the composition of the most important penitentials, seems most likely. It is, however, not inconceivable that practical books of Old Testament law were around in Ireland from earlier times.

\section{Manuscripts}

This edition is based on the four known surviving manuscript witnesses: Orléans 221 (A) of the ninth century from Brittany, ${ }^{27}$ Paris 3182 (B) of tenth-century Breton origin, ${ }^{28}$ London Cotton Otho E.XIII $(\mathbf{O})$ of the tenth century from a Breton exemplar, ${ }^{29}$ and the ninth-century Tours manuscript

${ }^{25}$ Hardinge, Celtic Church, p. x.

${ }^{26}$ Ibid., p. 202 (citation).

${ }^{27}$ Orléans, Bibliothèque municipale, MS 221 (193), saec. IXin., pp. 1-16; see Bernhard Bischoff, "Wendepunkte in der Geschichte der lateinischen Exegese im Frühmittelalter," Sacris Erudiri 6 (1954), 191-281, repr. in Mittelalterliche Studien, 3 vols., ed. B. Bischoff (Stuttgart, 1966-1981), 1:205-73, at 269; and Bernhard Bischoff, "Panorama der Handschriftenüberlieferung aus der Zeit Karls des Großen," in Karl der Große: Lebenswerk und Nachleben, 5 vols., ed. B. Bischoff (Düsseldorf, 1965-1968), 2:233-54, at 239; but compare Bieler, Irish Penitentials, p. 12, who dates the manuscript to the late eighth century.

${ }^{28}$ Paris, Bibliothèque nationale, MS lat. 3182 , saec. $\mathrm{X}^{2 / 2}$, pp. $1-12$; see Bischoff, "Wendepunkte," p. 269; compare Bieler, Irish penitentials, p. 12, who proposes a date in the first half of the tenth century.

${ }^{29}$ London, British Library, MS Cotton Otho E.XIII, saec. Xin., fols. 3v-9v; Bernhard Bischoff, Katalog der festländischen Handschriften des neunten Jahrhunderts (mit Ausnahme der wisigotischen), 2 vols. (Wiesbaden, 2005), 2:107-8; see also H. d'Arbois de Jubainville, 
Cambridge, Corpus Christi College $279(\mathbf{W}) .^{30}$ All four extant manuscripts are believed either to originate from Brittany, or to have been copied from Breton exemplars, on the evidence of Breton glosses, Breton proper names or both. Thus, $\mathbf{A}, \mathbf{B}$, and $\mathbf{O}$ have Breton glosses ( $\mathbf{W}$ possibly has a single Breton gloss ${ }^{31}$ ), and $\mathbf{A}$ and $\mathbf{B}$ also have scribal colophons containing Breton names.

A is the oldest copy of the Liber and the only extant manuscript in which (a later scribe) has given the text its title, including the incorrect genitive form of Moses. ${ }^{32}$ More than 300 Old-Breton glosses accompany the texts in A, most of which were entered by the main scribe, who identifies himself as Iunobrus. ${ }^{33}$ The bulk of the vernacular glosses were dated by Léon Fleuriot on linguistic grounds to the mid-ninth century. ${ }^{34}$ With regard to the many glosses accompanying the copy of the Hibernensis in the same manuscript, David Dumville remarked that the large number of vernacular glosses in this manuscript could reflect a first reaction to the reception of an unfamiliar text. The legal selection from the Pentateuch may equally have been unfamiliar to continental readers and may have inspired the Irish and Latin phrases glossing the Liber. ${ }^{35}$ The glosses in any case demonstrate a detailed and practical study of the texts in $\mathbf{A}$.

The base text of the current edition is provided by $\mathbf{A}$. Not only is it the oldest witness to the Liber, but it also has the most symptoms of Hiberno-Latin of the four copies with regard to abbreviation symbols

"Le manuscrit cottonien Otho E.xiii. La saisie irlandaise et galloise, le saisine bretonne," Revue celtique 7 (1886), pp. 238-40.

${ }^{30}$ Cambridge, Corpus Christi College, MS 279, saec. IX3/4, pp. 106-48; a detailed description of the manuscript is provided by Helen Simpson, "Ireland, Tours, and Brittany: The Case of Cambridge Corpus Christi College MS 279," in Irlande et Bretagne: vingt siècles d'histoire: Actes du Colloque de Rennes (29-31 Mars 1993), ed. C. Laurent and H. Davis (Rennes, 1994), pp. 109-23, at 110; see also Bischoff, Katalog, 1:180.

${ }^{31}$ See Simpson, "Ireland, Tours, and Brittany," p. 115.

${ }^{32}$ The title "Liber ex lege Moysi" is entered on page 1 in capitalis, a script not featured anywhere else in the manuscript, by a hand which Kottje dates to the tenth century, and therefore later than the main hand: Kottje, "Liber ex lege Moysis," p. 59. The main hand introduces the text with the words "Sanctus deus."

${ }^{33}$ Whitley Stokes, "The Breton Glosses at Orléans," Transactions of the Philological Society (1885-7), 539-618; Léon Fleuriot, Dictionnaire des gloses en vieux breton (Paris, 1964); David N. Dumville, "Ireland, Brittany, and England: Transmission and Use of Collectio canonum Hibernensis," in Irlande et Bretagne, ed. Laurent and Davis, pp. 85-95, at 89. The latin glosses were entered by the same scribe.

${ }^{34}$ Fleuriot, Dictionnaire, p. 4 (no. 3).

${ }^{35}$ Dumville, "Ireland, Brittany, and England," p. 89, n. 44. 
(o for con; $\mathrm{H}$ for enim; $\mathrm{h}$ for autem; $\overline{\mathrm{p}}$ for per) and spelling (though not strictly restricted to Hiberno-Latin) such as the more than occasional doubling of $s$ (assinus, occisserit), or a single $s$ instead of ss (percuserit), the use of $e$ for long $i$ (trea; in $\mathbf{W}$ we also find cremen/creminator), and $o$ for $u$ (motari) $)^{36} \mathbf{A}$ moreover has the largest number of idiosyncratic readings of biblical verses, sometimes resulting in decrees that are substantially different from those in the Vulgate. The many Irish symptoms and peculiar Bible readings lead me to conclude that the text in A probably best reflects the original wording and character of the Liber.

Another manuscript, W, has the fullest body of text with 13 (partial) verses that do not feature in copies $\mathbf{A}$ or $\mathbf{B}$. With the exception of Deuteronomy 18.10-12, these "W-verses" are placed according to the biblical order and adhere to the practical character of the Liber. $\mathbf{O}$, although on the whole preserving the shortest text, has two of the $\mathbf{W}$-verses, suggesting that these verses were in fact part of the original text of the Liber. The extra verses in $\mathbf{W}$ were almost certainly present in its exemplar, since they also occurred in the source from which the compiler of the $\mathbf{O}$-text made his selection, but they were apparently missing in the archetype of $\mathbf{A}$ and $\mathbf{B}$. It seems fair to assume that, while $\mathbf{A}$ with its Hiberno-Latin symptoms and Vulgate-variants preserves best the original wording and character of the Liber, $\mathbf{W}$ is probably closest to the original version in contents. ${ }^{37}$

For all practical purposes, the body of text of the Liber in Paris 3182 (B) is the same as the text in $\mathbf{A}$. The two manuscripts are closely related: the first 164 pages of $\mathbf{B}$ contain the same texts in the same order as $\mathbf{A}$, with the Liber as the first text of the manuscript. ${ }^{38}$ Ludwig Bieler concluded that textually A cannot be the direct exemplar of B, which lacks many of A's peculiar nonVulgate readings. Instead, $\mathbf{A}$ and $\mathbf{B}$ possibly derive from a common archetype in which the $\mathbf{W}$-verses were no longer present. The three later

${ }^{36}$ On symptoms of Hiberno-Latin, see the introduction in Bieler, Irish Penitentials, pp. 27-47; and Bengt Löfstedt, Der hibernolateinische Grammatiker Malsachanus (Uppsala, 1965), pp. 81-155; a strictly limited use of the term "hibernicism" is recommended by Michael Herren, "Sprachliche Eigentümlichkeiten in den hibernolateinischen Texten des 7. und 8. Jahrhunderts," in Die Iren und Europa im früheren Mittelalter, ed. Heinz Löwe (Stuttgart, 1982), 1: 425-33.

${ }^{37}$ Compare Kottje, "Liber ex lege Moysis," p. 64, where he states that A preserves the "ursprünglichen Textumfang."

${ }^{38}$ On pages 164 to 183 the contents run almost exactly parallel to the contents of folios $127 \mathrm{v}-139 \mathrm{v}$ of Paris lat. 12021, while the rest of $\mathbf{B}$ (pp. 184-356) is virtually identical to the contents of Cambrai 625 (576), a late ninth-century manuscript probably originating from Cambrai; Bieler, Irish Penitentials, pp. 21-23. 
manuscript copies all demonstrate a constant revision of the biblical citations by the copyists, probably to agree with the Bible text current in their own centre. It seems that in the dissemination and reception of the Liber nonVulgate readings were often corrected into Vulgate ones. This editing process is particularly evident in $\mathbf{B}$ and $\mathbf{W}$ and to a lesser extent $\mathbf{O}$. These redactions appear to have been undertaken independently, probably on the Continent, seeing that some corrections feature in $\mathbf{B}$ but not in $\mathbf{W}$ and vice versa. Furthermore, $\mathbf{W}$ has some unique idiosyncratic non-Vulgate readings (or Vulgate-variants) not attested in any of the other copies. This continuous process of emendation resulted in the loss of some of the more significant non-Vulgate readings.

Table 1: Contents

* passage only partly represented

\begin{tabular}{|c|c|}
\hline $1 \mathrm{Ex} 20.2$ ABOW & $26 \mathrm{Ex} 21.6 \mathrm{ABOW}$ \\
\hline 2 Ex 20.3 ABOW & $27 \mathrm{Ex} 21.7$ ABOW \\
\hline 3 Ex 20.4 ABOW & $28 \mathrm{Ex} 21.8 \mathrm{ABOW}$ \\
\hline $4 \mathrm{Ex} 20.5 \mathrm{ABOW}$ & $29 \mathrm{Ex} 21.9 \mathrm{ABOW}$ \\
\hline 5 Ex 20.6 ABOW & $30 \mathrm{Ex} 21.10 \mathrm{ABOW}$ \\
\hline $6 \mathrm{Ex} 20.7 \mathrm{ABOW}$ & $31 \mathrm{Ex} 21.11 \mathrm{ABOW}$ \\
\hline 7 Ex 20.8 ABOW & 32 Ex 21.12 ABOW \\
\hline 8 Ex 20.9 ABOW & 33 Ex 21.13 ABOW \\
\hline Ex 20.10* ABOW & $34 \mathrm{Ex} 21.14 \mathrm{ABOW}$ \\
\hline Ex 20.11 ABOW & $35 \mathrm{Ex} 21.15 \mathrm{ABOW}$ \\
\hline Ex 20.12 ABOW & $36 \mathrm{Ex} 21.16 \mathrm{ABOW}$ \\
\hline Ex 20.13 ABOW & $37 \mathrm{Ex} 21.17 \mathrm{ABOW}$ \\
\hline Ex 20.14 ABOW & $38 \mathrm{Ex} 21.18 \mathrm{ABOW}$ \\
\hline Ex 20.15 ABOW & $39 \mathrm{Ex} 21.19$ ABOW \\
\hline Ex 20.16 ABOW & $40 \mathrm{Ex} 21.20 \mathrm{ABOW}$ \\
\hline Ex 20.17 ABOW & $41 \mathrm{Ex} 21.21 \mathrm{ABOW}$ \\
\hline Ex $20.23 \mathrm{ABOW}$ & $42 \mathrm{Ex} 21.22 \mathrm{ABOW}$ \\
\hline Ex 20.24 ABOW & 43 Ex 21.23 ABOW \\
\hline Ex 20.25 ABOW & $44 \mathrm{Ex} 21.24 \mathrm{ABOW}$ \\
\hline Ex $20.26 \mathrm{ABOW}$ & $45 \mathrm{Ex} 21.25 \mathrm{ABOW}$ \\
\hline Ex 21.1 AOW & $46 \mathrm{Ex} 21.26 \mathrm{ABOW}$ \\
\hline Ex 21.2 ABOW & $47 \mathrm{Ex} 21.27 \mathrm{ABOW}$ \\
\hline Ex 21.3 ABOW & $48 \mathrm{Ex} 21.28 \mathrm{ABOW}$ \\
\hline $\mathrm{BOW}$ & $49 \mathrm{Ex} 21.29 \mathrm{ABOW}$ \\
\hline $\mathrm{Ex} 21.5 \mathrm{ABC}$ & $50 \mathrm{Ex} 21.20 \mathrm{ABOW}$ \\
\hline
\end{tabular}


51 Ex 21.31 ABOW

52 Ex 21.32 ABOW

53 Ex 21.33 ABOW

54 Ex 21.34 ABOW

55 Ex 21.35 ABOW

56 Ex 21.36 ABOW

$57 \mathrm{Ex} 22.1 \mathrm{ABOW}$

58 Ex 22.3* ABOW

59 Ex 22.4 ABOW

60 Ex 22.2 ABOW

61 Ex 22.3* ABOW

$62 \mathrm{Ex} 22.5$ ABOW

63 Ex 22.6 ABOW

64 Ex 22.7 ABOW

65 Ex 22.8 ABOW

66 Ex 22.9 ABOW

67 Ex 22.10 ABOW

68 Ex 22.11 ABOW

69 Ex 22.12 ABOW

70 Ex 22.14 ABOW

71 Ex 22.15 ABOW

72 Ex 22.16 ABOW

73 Ex 22.17 ABOW

74 Ex 22.18 ABOW

75 Ex 22.19 ABOW

76 Ex 22.20 ABOW

77 Ex 22.21 ABOW

78 Ex 22.22 ABOW

79 Ex 22.23 ABOW

80 Ex 22.24 ABOW

81 Ex 22.25 ABW

82 Ex 22.26 ABOW

83 Ex 22.27 ABOW

84 Ex 22.28 ABOW

85 Ex 22.29 ABOW

86 Ex 22.30 ABOW

87 Ex 22.31 ABOW

88 Ex 23.1 ABOW

89 Ex 23.2 ABOW
90 Ex 23.3 ABOW

$91 \mathrm{Ex} 23.4$ ABOW

92 Ex 23.5 ABOW

93 Ex 23.6 ABOW

94 Ex 23.7 ABOW

95 Ex 23.8 ABOW

96 Ex 23.9 ABW

97 Ex 23.10 ABOW

98 Ex 23.11 ABOW

99 Ex 23.12 ABOW

100 Ex 23.13 ABW

101 Ex 23.14 ABW

102 Ex 23.15* ABW

103 Ex 23.16 ABW

104 Ex 23.17 ABW

105 Ex 23.18 ABW

106 Ex 23.19 ABW

107 Ex 31.14 ABW

108 Lev 5.1 ABOW

109 Lev 6.1 ABW

110 Lev 6.2 ABW

111 Lev 6.3 ABW

112 Lev 6.4 ABW

113 Lev 6.5 ABW

114 Lev 6.6* ABW

115 Lev 7.19 ABW

116 Lev 7.20 ABW

117 Lev 7.24 ABW

118 Lev 7.26 ABOW

119 Lev 7.27 ABOW

120 Lev 11.33* ABW

121 Lev $11.35^{*}$ ABW

122 Lev 11.36 ABW

$123 \mathrm{Lev} 12.1 \mathrm{ABW}$

$124 \mathrm{Lev} 12.2 \mathrm{ABW}$

125 Lev 12.3 ABW

$126 \mathrm{Lev} 12.4$ ABW

$127 \mathrm{Lev} 12.5 \mathrm{ABW}$

128 Lev 12.6*? ABW 
129 Lev 17.10 ABW

130 Lev 17.11* ABW

131 Lev 17.13* ABW

132 Lev 17.14 ABW

133 Lev 17.15* ABOW

134 Lev 18.4* ABOW

135 Lev 18.5 ABOW

136 Lev 18.6* ABOW

137 Lev 18.7 ABOW

$138 \mathrm{Lev} 18.8 \mathrm{ABW}$

139 Lev 18.9 ABW

$140 \mathrm{Lev} 18.10 \mathrm{ABW}$

$141 \mathrm{Lev} 18.11 \mathrm{ABW}$

142 Lev 18.12 ABW

143 Lev 18.13 ABOW

$144 \mathrm{Lev}$ 18.14 ABO

145 Lev 18.15 ABOW

$146 \mathrm{Lev}$ 18.16 ABOW

147 Lev 18.17* ABOW

148 Lev 18.18 ABOW

149 Lev 18.19 ABOW

$150 \mathrm{Lev} 18.20$ ABOW

151 Lev 18.21 ABOW

152 Lev 18.22 ABOW

$153 \mathrm{Lev} 18.23$ ABOW

$154 \mathrm{Lev} 18.24 \mathrm{ABW}$

$155 \mathrm{Lev}$ 18.29 ABW

$156 \mathrm{Lev} 19.11 \mathrm{ABW}$

157 Lev 19.12 ABOW

158 Lev 19.13 ABOW

159 Lev 19.14 ABOW

160 Lev 19.15 ABOW

161 Lev 19.16 ABOW

162 Lev 19.17 ABOW

163 Lev 19.18 ABOW

164 Lev 19.19 ABOW

165 Lev 19.20 ABOW

166 Lev 19.21* ABOW

167 Lev 19.26 ABOW
168 Lev 19.27 ABOW

169 Lev 19.28* ABOW

170 Lev 19.31 ABOW

171 Lev 19.33 ABW

172 Lev 19.34* ABW

173 Lev 19.35 ABOW

174 Lev 19.36* ABOW

175 Lev $20.6 \mathrm{~W}$

176 Lev $20.7 \mathrm{~W}$

177 Lev 20.9* ABOW

178 Lev $20.10 \mathrm{ABW}$

179 Lev 20.11 ABW

180 Lev 20.14 ABW

181 Lev 20.12 ABOW

$182 \mathrm{Lev} 20.15$ ABOW

183 Lev 20.16 ABOW

184 Lev 20.17 ABW

185 Lev 20.18 ABOW

186 Lev 20.19 ABOW

187 Lev 20.20 ABOW

188 Lev 20.21 ABW

189 Lev 20.23 ABW

190 Lev 20.27 ABOW

191 Lev 22.8* ABW

192 Lev 22.14 ABW

193 Lev $22.21 \mathrm{ABW}$

194 Lev 22.22* ABW

195 Lev 24.15* ABW

196 Lev 24.16* ABW

197 Lev 24.18 ABW

198 Lev 24.19 ABW

199 Lev 24.20 ABW

200 Lev 24.21 ABW

201 Lev 24.22* ABOW

202 Lev 25.37 ABOW

203 Lev 27.1 ABW

204 Lev 27.2 ABW

205 Lev 27.3 ABW

206 Lev 27.5 ABW 
207 Lev 27.6 ABW 208 Lev 27.7 ABW 209 Lev 27.8 ABW 210 Lev 27.9 ABW 211 Lev 27.10 ABW 212 Lev 27.11 ABW 213 Lev 27.12 ABW 214 Lev 27.13 ABW 215 Lev 27.14 ABOW 216 Lev 27.15 ABOW 217 Lev 27.16 ABW 218 Lev 27.17 ABW 219 Lev 27.18 ABW 220 Lev 27.19 ABW 221 Lev 27.20 ABW 222 Lev 27.25 ABW 223 Lev 27.30 ABW 224 Lev 27.31 ABW 225 Lev 27.32 ABW 226 Lev 27.33 ABW 227 Lev 27.34 ABW 228 Num 27.7 ABOW 229 Num 27.8 ABOW 230 Num 27.9 ABOW 231 Num 27.10 ABOW 232 Num 27.11* ABOW 233 Num 35.30* ABOW 234 Num 35.31 ABOW 235 Deut 1.16* ABOW 236 Deut $1.17 *$ ABOW 237 Deut 6.4 ABW 238 Deut 6.5 ABW 239 Deut 6.6 ABW 240 Deut 6.7 ABW 241 Deut 6.8 ABW 242 Deut 6.9 ABW 243 Deut 6.13* ABW 244 Deut 6.16 ABW 245 Deut 7.26* ABW
246 Deut 13.1 ABW 247 Deut 13.2 ABW 248 Deut 13.3 ABW 249 Deut 13.4* ABW 250 Deut $14.21 *$ ABW 251 Deut $14.22 \mathrm{~W}$ 252 Deut $14.23 \mathrm{~W}$ 253 Deut 16.19 OW 254 Deut $16.20 \mathrm{~W}$ 255 Deut $17.1 \mathrm{~W}$ 256 Deut 17.6 ABW 257 Deut 19.4 ABW 258 Deut 19.5 ABW 259 Deut 19.11 ABW 260 Deut 19.12 ABW 261 Deut 19.13* ABW 262 Deut $18.10 \mathrm{~W}$ 263 Deut $18.11 \mathrm{~W}$ 264 Deut $18.12 *$ W 265 Deut 19.15 OW 266 Deut 19.16 ABOW 267 Deut 19.17 ABOW 268 Deut 19.18 ABOW 269 Deut 22.5 ABOW 270 Deut 22.6 ABOW 271 Deut 22.7 ABOW 272 Deut 22.8 ABW 273 Deut 22.28 ABOW 274 Deut 22.29 ABOW 275 Deut $22.19 \mathrm{~W}$ 276 Deut 22.20* W 277 Deut 23.21 ABOW 278 Deut 23.22 ABOW 279 Deut 23.23 ABOW 280 Deut 24.16 ABOW 281 Deut 24.17 ABOW 282 Deut 25.13 ABOW 283 Deut 25.14 ABOW 284 Deut 25.15 ABOW 
285 Deut 25.16* ABOW

286 Deut 27.15 ABOW

287 Deut 27.16 ABOW

288 Deut 27.17 ABOW

289 Deut 27.18 ABOW

290 Deut 27.19 ABOW

291 Deut 27.21 ABOW
292 Deut 27.20 ABOW

293 Deut 27.22 ABOW

294 Deut 27.23 ABOW

295 Deut 27.24 ABOW

296 Deut 27.25 ABOW

297 Deut 27.26 ABOW

\section{Edition}

The main text of the present edition of the Liber is based on A. My printed text is a diplomatic edition: the orthography is unchanged and grammatical or factual errors are preserved. On the occasions that the original has been modified in the manuscript, the changed reading is presented in the printed text, while the change is indicated in the apparatus criticus (as: $n$ corr. $m$ ).

In the main text, the extra verses in $\mathbf{W}$ and $\mathbf{O}$ are printed in italics and supplied by $\mathbf{W}$, with variant readings in $\mathbf{O}$ in the notes. Marginal notes signal in which manuscripts the additional verses occur.

$\mathbf{O}$ was damaged in the Cottonian fire, which has resulted in the loss of parts of the text. For ease of reading, I have not signalled the lost parts of $\mathbf{O}$ in the edition. The absence of a variant reading for $\mathbf{O}$ in the notes, therefore, may not necessarily indicate a correspondence between the reading in $\mathbf{O}$ with the reading in $\mathbf{A}$, but could reflect the loss of that portion in $\mathbf{O}$. The sources for the Liber are the Bible books of Exodus, Leviticus, Numbers, and Deuteronomy. The biblical references are presented in the printed text itself. Asterisks $(*)$ are used to indicate where a Bible verse was truncated.

\section{Apparatus glossarum}

All copies of the Liber are accompanied by glosses, both in Latin, as well as in the vernaculars (Old-Irish and Old-Breton). While interlinear additions and emendations to the text are recorded in the apparatus criticus, explanatory glosses (either translations of Latin words or phrases, or interpretative comments) are presented in the second level of footnotes, following the glossed word. Where possible, I have included short English translations for the vernacular glosses.

\section{Apparatus criticus}

The following variants are recorded in the apparatus criticus: added/missing words or phrases, variations in word order, variations in spelling. 
Abbreviations

Dict. Léon Fleuriot, Dictionnaire des Gloses en vieux Breton (Paris, 1964).

DIL Dictionary of the Irish Language

Thes.Pal. Whitley Stokes and John Strachan (eds.), Thesaurus Palaeohibernicus: A Collection of Old-Irish Glosses, Scholia, Prose, and Verse (Cambridge, 1903).

Stokes Whitley Stokes, "The Breton Glosses at Orléans," Transactions of the Philological Society (1885-7), pp. 539618.

Sigla

A Orléans, Bibliothèque municipale, MS 221 (193)

$\mathrm{B}$ Paris, Bibliothèque nationale, MS lat. 3182

O London, British Library, MS Cotton Otho E.XIII

W Cambridge, Corpus Christi College, MS 279

Sven Meeder, Trinity College Cambridge 


\title{
Sanctus deus liber ex lege moisi
}

Ex 20.2 Ego sum dominus deus tuus, qui eduxit te de terra aegypti, de domo seruitutis. Ex 20.3 Non habebis deos alienos coram me. Ex $5 \quad 20.4$ Non faciaes tibi scluptile, neque omnem similitudinem que est in caelo desuper et que in terra deossum, neque eorum que sunt in aquis sub terra. Ex 20.5 Non adorabis ea, neque coles: ego sum dominus deus tuus fortis et zelotis, uisitans iniquitatem patrum in filios, in tertiam et quartam generationem eorum qui oderunt me: Ex 20.6 et faciens

10 misericordiam in milia his qui diligunt mea precepta. Ex 20.7 Non adsummes nomen domini dei tui in uanum: neqae enim hodio habebit insontem dominus eum qui adsumpserit nomen domini dei frustra iuramento. Ex 20.8 Memento diaem sapati et sanctifices. Ex 20.9 VI diebus operaberis et facies omnia opera tua. Ex 20.10* VIIa diae sapati domini dei tui: non facies omne opus tuum et filius tuus et filia tua et seruus tuus et ancilla tua et iumentum tuum et aduena qui est intra

\author{
3 p. 1 A p. 1 B fol. $3 v$ O p. $106 \mathrm{~W} 9$ fol. 4 r O 15 p. $107 \mathrm{~W}$ \\ 4 deos alienos ] .i. uitia interlinear $\mathrm{W}$ \\ 5 scluptile] .i. idola interlinear $\mathrm{W}$ \\ 6 in terra deossum ] ignem et ligna et lapides margin W \\ 6-7 que sunt in aquis sub terra ] .i. animalia maris interlinear $\mathrm{W}$ \\ 7 Non adorabis ea ] i. flectendo genua interlinear W \\ 7 neque coles ] i. dones interlinear W \\ 14 operaberis ] accipiet iudicium filii margin A \\ 14 VIIa diae ] iubelius VII annorum interlinear W
}

liber ex lege moisi] Incipiunt uerba pauca tam de episcopo qua de presbitero aut de omnibus ecclesiae gradibus et de regibus et de mundo et terra $\mathrm{B}$ no title OW 3 Ego] ego enim W eduxit te ] eduxi te BOW aegypti] egypti B aegypti et W 4 seruitutis ] seruitutis, dixit dominus moysi B habebis ] habebitis B $\mathbf{5}$ faciaes ] facies BOW scluptile] sculptile $\mathrm{O}$ que ] quae BW 6 caelo] celo B 6-7 in terra...coles] margin A que] quae BW deossum] deorsum B que ] quae BW 10 misericordiam] [misericord]iam $O$ misericordias $W$ mea precepta] me et custodiunt precepta mea B precepta] prae[cepta] O $\mathbf{1 1}$ adsummes] assumen B adsumes OW nomen] deest $\mathrm{B}$ neqae ] neque BOW hodio] deest BW 1112 habebit insontem ] insontem habebit W 12 adsumpserit ] assumpserit B adsumerit $\mathrm{W}$ domini] deest $\mathrm{B}$ dei] deest $\mathrm{O}$ dei sui $\mathrm{BW}$ frustra] frustri $\mathrm{W} 13$ iuramento ] deest B Memento diaem ] Memento ut diem B diaem ] diem OW sapati] sabbati BW [...] ti O et sanctifices ] sanctifices BW VI] sex BW 14 operaberis ] operabiris W VIIa diae ] Septimo die B VII die O VII autem diem W sapati] sabbati BO sabbatum W 15 tuum ] tu BW 16 et seruus ] seruus BOW et ancilla ] ancilla $\mathrm{B}$ [et] ancilla $\mathrm{O}$ et iumentum tuum ] iumentum tuum BO iumentuum W 
portas tuas. Ex 20.11 VI enim diebus fecit deus caelum et terram et cuncta que in eis sunt, et requiaeuit in diae septimo: idcirco benedixit dominus diem sabati et sanctificauit eum. Ex 20.12 Honora patrem tuum

20 et matrem tuam, ut sis longeus super terram, qua dominus deus tuus dabit. Ex 20.13 Non occides. Ex 20.14 Non mechaberis. Ex 20.15 Non furtum facies. Ex 20.16 Non dices contra proximum tuum falsum testimonium. Ex 20.17 Non concupisces domum proximi tui, non desiderabis uxorem eius, non seruum, non ancillam, non bouem, non assinum, nec omnia

25 que illius sunt. Ex 20.23 Dixit quoque dominus: Non faciaetis uobis deos argenteos, nec deos aureos facietis uobis. Ex 20.24 Altare de terra faciaetis mihi et offeretis super eum holocausta et pacifica uestra, oues uestras, et boues in omni loco in quo memoria fuerit nominis mei ueniam ad te et benedicam tibi. Ex 20.25 Quod si altare lapideum

30 feceritis, nec aedificabitis illud defectis lapidibus: si enim leuaueris cultrum tuum super eum, pulluetur. Ex 20.26 Non ascendes per gradus ad altare meum, ne reueletur turpitudo tua. Ex 21.1 Haec sunt iudicia que propones illis. Ex 21.2 Si enim emeris seruum ebreum; IIII annis seruiet: in VII egredietur liber gratis. Ex 21.3 Cum quali ueste intrauerit cum tali exeat; si habet uxorem et uxor egredietur simul. Ex 21.4 Si autem dominus eius dederit ei uxorem et peperit filios et filias, mulier et liberi

\section{8 p. 108 W 30 p. 2 B 34 p. 2 A}

21 Non occides ].i. malo exemplo interlinear $\mathrm{W}$

29 ueniam ad te ] quique bonum offerat deo interlinear $\mathrm{W}$

30 defectis ] .i. nasibus interlinear $\mathrm{W}$

31 pulluetur ] i. preter modum edifices $\mathrm{W}$

36 dominus ] spiritaliter princeps margin $\mathrm{W}$

36 uxorem ] sapientia senius utriusque sexus interlinear $\mathrm{W}$

$17 \mathrm{VI}$ ] In sex B VII W caelum ] celum B terram ] terram et mare B terram mare W 18 que] quae BOW requiaeuit] requieuit BOW diae] die BOW idcirco ] iccirco B 19 sabati] sabbati BOW 20 longeus] longeuus BO qua] quam BW 21 dabit] dabit tibi BOW mechaberis] moechaberis OW 24 assinum] asinum BW asinam O 25 que] illegible B quae OW illius] in eis $W$ faciaetis ] facietis BOW uobis] deest $\mathrm{O} 26$ deos aureos] aureos deos W 27 faciaetis] facietis BW eum ] illud B uestra] uestram O 28 uestras ] uestra W 28-29 fuerit nominis mei] nominis mei fuerit W $\mathbf{3 0}$ feceritis ] feceritis mihi W nec] non W aedificabitis ] edificabitus BW defectis ] desectis W leuaueris ] lauaueris W 31 eum] illud BW pulluetur] polluetur B 32-33 Haec...illis] deest B que] quae $\mathrm{OW} 33$ enim ] deest BW ebreum; IIII annis] hebreum sex annis B ebreum VI annis O hebreum VI annis W seruiet] seruiae tibi B seruiet tibi W 34 VII] septimo B Cum quali] cumque tali $\mathrm{W}$ intrauerit] introierit $\mathrm{B} 35$ exeat] exiet $\mathrm{W}$ habet] habens $\mathrm{B}$ egredietur] egrediatur $\mathrm{B} \mathrm{Si}] \sin \mathrm{W} \quad \mathbf{3 6}$ eius ] deest $\mathrm{B}$ ei] illi $\mathrm{B}$ liberi] liberi eius B 
erunt domini sui; ipsae uero exibit cum uestimento suo. Ex 21.5 Quod si dixerit seruus: diligo dominum meum et uxorem ac liberos; ne egredias liber: Ex 21.6 Offeret eum dominus domino et adplicabitur ad hostium et ad postes, perforauitque aurem eius sopula: et erit seruus in saeculum. Ex 21.7 Si quis uendiderit filiam suam in famulam non egrediaetur sicut ancellae exirae consuerunt. Ex 21.8 Si displicuerit oculis domini sui cui tradita fuerit, dimittet eam: populo omne alieno uendidi non habet potestatem, si spreuerit eam. Ex 21.9 Si autem filio suo disponderit eam, iuxta morem filiarum faciet illi. Ex 21.10 Si alteram ei acciperit, prouidebit puellae nuptias et uestimenta. Et pretium puditiae non negabit. Ex 21.11 Si trea ista non fecerit egrediaetur gratis absque pecunia.

Ex 21.12 Qui percusserit hominem uolens occidere eum morte moriatur.

\section{0 p. $109 \mathrm{~W}$}

37 uestimento suo ] i. iustitia W

39 adplicabitur ] tin ol fiter interlinear W; for tinólfither, 'he shall be assembled' (Ir.), cf. DIL, s. do-inola.

40 aurem ] .i. auditus uerbi dei interlinear $\mathrm{W}$

40 sopula ] mi interlinear A; perhaps for word corresponding with menauet (Bret.), 'awl', cf. Dict., 255-6.

41 non egrediaetur ] liberior erit si seruierit W

42-43 cui tradita fuerit ] i. alio de cogitatione interlinear $\mathrm{W}$

45 alteram ei acciperit ] .i. uxorem filio interlinear $\mathrm{W}$

46 prouidebit] i. si dotabit eam interlinear $\mathrm{W}$

46 puellae ] i. ancillae interlinear $\mathrm{W}$

46 nuptias ] banessa interlinear W, 'weddings' (Ir.), cf. DIL, s. banais.

46 uestimenta] .i. brotligi interlinear W, 'garments' (Ir.), cf. DIL, s. brotlach.

$47 \mathrm{Si}$ trea ista non fecerit ] .i. mari aranastar interlinear W; for maniarnastar, 'if she be not betrothed' (Ir.), cf. DIL, s. ar-naisc.

49 morte moriatur ] i. penitentia interlinear $\mathrm{W}$

37 ipsae ] ipse BW exibit] exeat B uestimento ] uestitu B 38 dixerit seruus ] seruus dixerit $\mathrm{W}$ ne] non BOW egredias] egrediar BW 39 dominus] dominus eius B adplicabitur] applicabitur B hostium] hostium tabernaculi W 40 ad postes] postes $\mathrm{W}$ perforauitque] perforabitque BOW aurem ] ad aurem W sopula] subula BW sub[ula] O erit] erit ei B 41 egrediaetur] egredietur BOW $\mathbf{4 2}$ ancellae ] ancillae $\mathrm{BO}$ deest $\mathrm{W}$ exirae ] exire BOW consuerunt ] consueuerunt BO oculis ] in oculis $\mathrm{W} 43$ dimittet ] dimitet $\mathrm{O}$ populo] popula corr. populo $\mathrm{A}$ omne] interlinear A deest $\mathrm{B}$ autem OW alieno] aliena corr. alieno $\mathrm{A}$ aliaeno $\mathrm{O}$ uendidi] uendendi BOW habet] habebit W $\mathbf{4 4}$ spreuerit] spreuit B spreuit later corr. spreuerit $\mathrm{O}$ 45 alteram ] alterum B acciperit] acceperit B 46 pretium ] precium B praetium O puditiae ] pudicitiae BOW 47 trea ] tria BO egrediaetur ] egredietur BOW gratis ] gratias W 49 eum ] deest $\mathrm{W}$ 
50 Ex 21.13 Qui autem non est insidiatus, sed deus illum tradit in manu eius, constituam tibi locum co fugere debeat.

Ex 21.14 Si quis de industria occiderit proximum et per insidias: ab altari meo euelles eum, ut moriatur.

21.15 Qui percuserit patrem suum et matrem suam, morte moriatur.

55 Ex 21.16 Qui fraudatus fuerit hominem, conuictus. Noxiae mortae moriatur.

Ex 21.17 Qui maledixerit patri suo uel matri, mortae moriatur.

Ex 21.18 Si rixati fuerint uiri et percuserit alter proximum suum lapide uel pugno, et ille mortuos non fuerit et iacuerit in lecto: Ex 21.19 si

60 surrexerit et ambulauerit foris super baculum suum innocens erit qui percusit ita tamen ut opera eius et inpensa in medico restituet.

Ex 21.20 Qui percuserit seruum suum uel ancella uirga et mortui fuerint in manibus criminis erit reus. Ex 21.21 Sin autem uno diae si superuixerit uel duobus non subiacebit pene quia pecunia eius est.

65 Ex 21.22 Si rixati fuerint uiri et percuserit quis mulierem et abortum fecerit, sed illa uixerit: subiacebit damno quantum expetiarit maritus

\section{5 p. $110 \mathrm{~W}$ fol. 5 r O}

52 industria ] guo interlinear A, for *guodau (?, Bret.), 'intention', cf. Dict., 194.

61 in medico] .i. mertis medici margin $\mathrm{W}$

66 expetiarit ] ar interlinear A (Bret.?), as the beginning of a verb, such as Ir. arco, 'to beseech', cf. Stokes, 546.

50 insidiatus ] insidiatur $\mathrm{W}$ illum tradit] tradidit illum B tradit] tradidit W 51 tibi] ei interlinear $\mathrm{O}$ co fugere ] quo fugere $\mathrm{BOW}$ co ] for quo $\mathbf{5 2}$ occiderit ] occididerit corr. occiderit A proximum ] proximum suum BW $\mathbf{5 3}$ meo] in eo $\mathrm{W}$ euelles] reuelles B $\mathbf{5 4}$ percuserit] percusserit BW et] aut B $\mathbf{5 5}$ fraudatus ] furatus B fradus W hominem ] hominem et uendiderit eum BW mortae ] morte BOW $\mathbf{5 7}$ mortae ] morte BOW $\mathbf{5 8}$ et] ad corr. et A percuserit] percusserit BOW 59 uel] aut B pugno] puno corr. pugno A mortuos] mortuus BOW lecto] lectulo BOW 61 percusit] percusserit BW percussit O inpensa] inpensas BOW medico] medicos BOW restituet] restituat BOW $\mathbf{6 2}$ percuserit] percusserit BW [per]cusserit $\mathrm{O}$ suum ] deest $\mathrm{O}$ ancella ] ancillam BOW 63 manibus ] manibus eius BW criminis] creminis W erit reus] reus erit BO Sin] Si B uno] una W diae ] die BW si] deest BOW superuixerit ] superuixerint B 64 non] non qui percusserit $\mathrm{W}$ subiacebit] iacebit $\mathrm{W}$ 64-66 pene... subiacebit] deest $\mathrm{O}$ The scribe of $O$ here skipped a line. In the margin a later scribe entered: uel poenae expe[...] fuerint uiri [...]erem et aborteum [...] uixerit subi[...] pene ] penae $\mathrm{B}$ poaenae $\mathrm{W}$ eius ] illius BW 65 fuerint] fuerit W percuserit] percusserit BW mulierem ] mulierem pregnantem BW 66 illa] ipsa W damno] dampno BW interlinear qui percusserit W expetiarit] expetiaerit corr. expetiarit A expetierit BOW 
mulieris et arbitri iudicauerint. Ex 21.23 Sin autem mors subsecuta reddet animam pro anima, Ex 21.24 oculum pro oculo et dentem pro dente, manum pro manu pedem pro pede, Ex $\mathbf{2 1 . 2 5}$ adustionem pro adussione, uulnus pro uulnere, liuorem pro liuore. Ex 21.26 Si percuserit quispiam oculum serui sui aut ancellae et luscos eos fecerit, dimittat eos liberos pro oculo quem eruit. Ex 21.27 Dentem ergo si excuserit seruo uel ancille suae similiter dimitat eos liberos.

Ex 21.28 $\mathrm{Si}$ bos cornu percuserit uirum aut mulierem et mortui fuerint

75 lapidibus abruatur: et non comedentur carnes eius, dominus autem bouis innocens erit. Ex 21.29 Quod si bos cornupeta fuerit ab heri et nudustertius et contestati sunt domino eius nec reclusus erit eum occideritque uirum aut mulierem: et bos lapidibus obruatur, et dominum illius occident. Ex 21.30 Quod si pretium eius fuerit inpositum dabit pro anima sua quidquid fuerit postolatus. Ex 21.31 Si cornu percuserit simili sententiae subiacebit filium quoque aut filiam. Ex 21.32 Si seruum aut ancillam inuasserit XXX siclos argenti dabit domino et bos lapidibus obruatur.

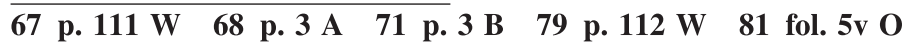

67 arbitri ] on interlinear A; for *onmanerion, 'unifiers, concilatiors' (? Bret.), cf. Dict., 276.

68 oculum pro oculo et dentem pro dente] si tantum frangit reddet vicem interlinear $\mathrm{W}$

69 adustionem ] cis interlinear A, 'a blow', cf. Dict., 108-9.

$82 \mathrm{XXX}$ siclos argenti] siclus $\mathrm{XX}$ ouelus habet ouelis autem de medium scripuli $\operatorname{margin} \mathrm{W}$

67 arbitri] ab arbitrii $\mathrm{W}$ mors] mors eius fuerit $\mathrm{B}$ mors fuerit $\mathrm{W}$ subsecuta ] subsequuta $\mathrm{BO}$ later interlinear addition eius fuerit $\mathrm{O} \quad \mathbf{6 8}$ animam ] anima W 69 adussione ] adustione BOW $\mathbf{7 0}$ uulnere ] uulne W percuserit ] percusserit BOW 71 ancellae ] ancillae suae $B$ ancillae $O W$ fecerit] fecrit $W$ dimittat] dimitat $O$ demittet W 72 Dentem ] et dentem W ergo] uero O deest W si] si percusserit seruo si $\mathrm{W}$ excuserit] excusserit $\mathrm{O}$ uel] aut $\mathrm{W}$ ancille] ancillae BOW 73 dimitat] dimittat BO dimittet corr. dimittat W $\mathbf{7 4}$ percuserit ] percusserit $\mathrm{O}$ petierit $\mathrm{W} \mathbf{7 5}$ abruatur ] for obruatur; obruatur $\mathrm{BO}$ obruetur $\mathrm{W}$ comedentur ] commedentur B 77 et ] uel W nudustertius ] nudiustertius B nudusterciu[s] O reclusus erit] recluserit BW $\mathbf{7 8}$ obruatur] obruatus $\mathrm{O}$ obruetur W $\mathbf{7 9}$ eius] deest B ei $\mathrm{W}$ fuerit inpositum ] inpositum fuerit $\mathrm{W} \mathbf{8 0}$ quidquid] quicquid $\mathrm{W}$ postolatus ] postulatus BW 80-81 Si... filiam] filium quoque aut filiam si cornu percuserit simili sententiae subiacebit B filium quoque aut filiam si cornu percusserit simili sentiae subiacebit W 82 aut] uel W ancillam ] ancellam corr. ancillam A inuasserit] inuaserit $\mathrm{B} 83$ et] deest $\mathrm{W}$ bos] bos uero $\mathrm{W}$ obruatur] obru[...] O obruetur W 
Ex 21.33 $\mathrm{Si}$ quis aperuerit cisternam et foderit et non operuerit eam cecideritque bos uel assinus in ea, Ex $\mathbf{2 1 . 3 4}$ dominus cisternae redet pretium iumentorum: quod hoc est mortuum ipsius erit.

Ex 21.35 $\mathrm{Si}$ bos alienus bouem alterius uulnerauerit et ille mortuus fuerit: uendent bouem uiuum et diuident pretium eius cadauer autem mortui inter se dispertient.

90 Ex 21.36 $\mathrm{Si}$ autem sciebat quod bos cornupeta esset ab heri et nudustersius et non custodiuit eum dominus suus redet bouum pro boue et cadauer integrum accipiet.

Ex 22.1 Si quis furatus fuerit bouem aut ouem et occiderit uel uenderit: $\mathrm{V}$ boues pro uno boue restituet et IIII oues pro una oue restituet 95 Ex 22.3* si non habuerit quod pro furto redat uerundabitur. Ex 22.4 Si inuentum fuerit apud eum quod furatus est uiuens: siue bos, siue assinus, siue ouis, duplum restituet.

Ex 22.2 Si effringens fur domum siue soffodiens fuerit inuentus, et accepto uulnere mortuus fuerit, percusor non erit reus sanguis. Ex

100 22.3* Quod si ortu sole hoc fecerit, homicidium perpetrauit, et in ipso morietur.

Ex 22.5 Si leserit quispiam agrum uel uineam, et dimiserit iumentum

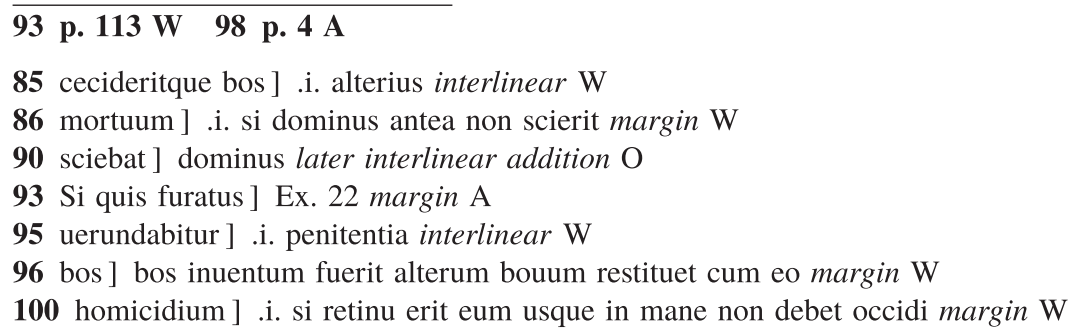

84 operuerit] aperuerit corr. operuerit B 85 cecideritque ] [ceci]deritque O uel] aut $\mathrm{B}$ assinus ] asinus OW ea ] eam W redet] reddet BW $\mathbf{8 6}$ hoc] autem BOW 87 alienus ] aliaenus $\mathrm{O}$ alterius uulnerauerit ] uulnerauerit alterius $\mathrm{W}$ uulnerauerit ] uuln[eraue]rit $\mathrm{O} \mathbf{8 8}$ uiuum] unum $\mathrm{W}$ pretium] praetium $\mathrm{O} \mathbf{8 9}$ dispertient] disperdent B dispertiat W 90 esset ] esse B nudustersius ] nudiustertius B nudustertius OW 91 redet] reddet BOW bouum ] bouem BO boue] boe $\mathrm{B} 93$ bouem ] boem $\mathrm{B}$ uenderit] uendiderit BOW $94 \mathrm{~V}$ ] Ve $\mathrm{O}$ quinque $\mathrm{W}$ boues] boes $\mathrm{B}$ et. . restituet] et IIIIor oues pro una [... ] later interlinear addition $\mathrm{O}$ IIII] quatuor $\mathrm{W}$ restituet ] deest $\mathrm{W} 95$ redat ] reddat $\mathrm{BO}$ reddet $\mathrm{W}$ uerundabitur ] uenundabitur BOW 96 siue bos] si bos W 97 assinus] asinus W 98 effringens] effrigens W soffodiens] suffodiens B effodie[ns] O suffudens W fuerit] foerit corr. fuerit O inuentus ] inuentis $\mathrm{W} 99$ uulnere ] deest $\mathrm{W}$ percusor ] percussor BOW sanguis ] sanguinis BOW 100 ortu] orto BO 101 morietur] mo[rietur] $O \quad 102$ leserit] lesserit BW 
suum ut depastatur aliena: quidquid obtimum habuerit in agro suo, uel in uinea, pro damni estimatione restituet.

105 Ex 22.6 Si egresus ignis inuenerit spinas, et incenderit aream aut segetem aut uineas aut campum uel conprehenderit aceruos frugum siue stantes segetes in agros, reddet dampnam qui ignem succenderit.

Ex 22.7 $\mathrm{Si}$ quis commendauerit amico pecuniam suam aut uas in custodiam, et ab eo, qui susciperat, furto et ablatum fuerit: si

110 inuenitur duplum reddet: Ex 22.8 si latet dominus domus amplicabitur ad deos, et iurabit quod non extenderit manum in rem proximi, Ex 22.9 ad perpetrandam fraudem, tam in boue quam in assino et oue ac uestimento et quidquid dampnum inferre potest et ad deos utriusque causa perueniet, et si illi iudicauerint, dampnum restituet domino suo.

115 Ex 22.10 Si quis commendauerit proximo suo assinum, bouem, ouem et omne iumentum ad custodiam, et mortuum fuerit, aut debilitatum uel captum ab hostibus et nullus hoc uiderit: Ex 22.11 iusiurandum erit et ille reddere non cogitur. Ex 22.12 Quod si furto ablatum fuerit restituet

\section{6 p. $114 \mathrm{~W} 108$ fol. 6r O 116 p. 4 B $\quad$ p. $115 \mathrm{~W}$}

104 pro damni estimatione restituet ] si nescierit innocens erit uel modicum restiti later addition sine fur margin $\mathrm{W}$

106 aceruos ] desi interlinear A; plural of das, 'heaps, collections', cf. Dict., 136.

109 ablatum fuerit ] qui .i. suscipit interlinear W

113 dampnum inferre potest ] .i. scis interlinear $\mathrm{W}$

113-114 utriusque causa ] .i. qui dedit et qui accipit .i. si magnum aut minimum interlinear $\mathrm{W}$

116 debilitatum ] indenim margin W; 'weak, debilitated', Thes.Pal., ii. 38.

103 depastatur ] depascatur BOW aliena ] aliaena $\mathrm{O}$ quidquid] quicquid $\mathrm{W}$ obtimum ] optimum W 104 damni] dampni W estimatione] aestimatione W 105 egresus ] egressus BOW segetem ] segitem W 106 uineas ] uineam W 107 segetes] segites W agros] agris BW dampnam ] damnum corr. dampnum B damnum W succenderit] incenderit W 109 et ablatum] ablatum BOW 110 inuenitur ] inuenitur fur $\mathrm{BO}$ inueniatur fur $\mathrm{W}$ reddet ] [.]estituet $\mathrm{O}$ dominus ] dominum W amplicabitur] adplicabitur BW adplica[bitur] O 111 manum] manum suam $\mathrm{W}$ proximi] proximi sui BOW $\mathbf{1 1 2}$ perpetrandam ] perpetrandum $\mathrm{W}$ boue ] boe $\mathrm{B}$ assino] asino OW 113 quidquid] quicquid BW dampnum ] [da]mnum $\mathrm{O}$ inferre ] inferri B et] deest BOW 114 dampnum] underlined A duplum $\mathrm{OW}$ restituet ] restituat interlinear addition uel e $\mathrm{O}$ domino ] proximo $\mathrm{W}$ 115 commendauerit ] comendauerit $\mathrm{W}$ assinum ] asinum aut $\mathrm{O}$ asinum $\mathrm{W}$ bouem ] bouem aut $\mathrm{O} \mathbf{1 1 7}$ ab hostibus ] a bestiis $\mathrm{B}$ ab hostibus uel a bestiis $\mathrm{W}$ erit ] erit in medio quod non extenderit manum in rem proximi sui et suscipiet dominus (interlinear: i. in quo commendatum est) iuramentum W $\mathbf{1 1 8}$ cogitur ] cogetur OW 118-119 Quod... domino] This sentence follows the next B furto] in furto $\mathrm{W}$ ablatum ] sublatum $\mathrm{W}$ 
domino. Si comestum a bestia deferet ad eum quod occisum est, et non restituet.

Ex 22.14 Qui a proximo suo quicquam horum mutuum postolauerit et debilitatum aut mortuum fuerit domino non presente reddere conpellitur. Ex 22.15 Quod si in presenti fuerit dominus, non restituet, maxime si conductum uenerat pro mercede operis sui.

Ex 22.16 Si seduxerit quis uirginem necdum disponsatam uiro et dormierit cum ea: dotauit eam, et habebit eam uxorem. Ex 22.17 Si pater uirginis dare noluerit, reddet pecuniam iuxta modum dotis, quam uirgines accipere consueuerunt. Ex 22.18 Maleficos non patieris uiuere.

Ex 22.19 Qui coierit cum iumento, morte moriatur.

Ex 22.20 Qui immolat diis, occidatur, preter soli d[e]o. Ex 22.21 Aduenam non contristaberis, neque adfliges eum: aduenae et enim fuistis in terra egipti.

Ex 22.22 Uiduam et pupillum non nocebitis. Ex 22.23 $\mathrm{Si}$ enim lesseritis, uociferabuntur ad me et ego audiam clamorem earum: Ex 22.24 et indignabitur furor meus, percutiamque uos gladio, et erunt uxores uestrae uidue et filii uestri pupilli.

Ex 22.25 Si pecuniam dederis mutuam populo meo pauperi qui habitat tecum non urges eum quasi exactor nec ussuriis obprimes.

\section{6 p. 116 W 127 p. 5 A 131 fol. 6v A 138 p. 117 W}

126 dotauit ] c interlinear A, perhaps for a verb cognate with Welsh cynnysgaethu, 'to endow', cf. Stokes, 547; and Dict., 92.

137 populo ] i. mercis mercinari i. seruis interlinear $\mathrm{W}$

119 domino ] deest $\mathrm{B}$ domino damnum $\mathrm{O}$ dampnum domino $\mathrm{W}$ comestum ] commestum $B$ deferet] defert $\mathrm{BO}$ deferat $\mathrm{W}$ occisum] occissum BW 121 a] deest $\mathrm{W}$ mutuum ] motuum $\mathrm{W}$ postolauerit] postulauerit $\mathrm{BO} \mathbf{1 2 2}$ et debilitatum...fuerit] deest B $\mathbf{1 2 3}$ conpellitur] conpelletur W presenti] presentia (a overhead) $\mathrm{O} 124$ uenerat ] deest $\mathrm{O}$ mercede ] mercide W 125 quis ] quispiam W 126 dotauit ] for dotabit; dotabit BOW et habebit eam] interlinear B uirginis ] [uir]gines O 127 noluerit] uoluerit B quam ] quod W 128 consueuerunt] consuerunt corr. consueuerunt B consuerunt W patieris ] patiris W $\mathbf{1 3 0}$ soli d[e]o ] soli deo B deo soli W 131 contristaberis ] contristabis W adfliges ] affliges B eum ] a overhead W aduenae ] aduene W enim ] enim ipsi W 132 egipti] aegypti BOW 133 pupillum ] pupillam corr. pupillum B enim ] deest $\mathrm{W}$ lesseritis] leseritis BO lesseritis eos W 134 uociferabuntur] uociferentur B uociferabunt[ur] O uociferabunt W audiam ] exaudiam W earum ] eorum BOW 135 percutiamque ] et percutiam W uos ] eos B 136 uidue ] uiduae BW 137-138 Si pecuniam... obprimes] deest O 138 ussuriis ] usuris W obprimes ] opprimes eum W 
Ex 22.26 $\mathrm{Si}$ pignus a proximo tuo acciperis uestimentum, ante solis occassum redes. Ex 22.27 Ipsum enim est solum, quo operitur indumentum carnis eius, nec habet aliud in quo dormiat: si clamauerit ad me, exaudiam eum, quia misericors sum.

Ex 22.28 Diis non detrahes.

Principem populi tui non maledices. Ex 22.29 Decimas tuas et primitias non tardabis offerre: primogenitum filiorum tuorum dabis mihi.

Ex 22.30 De bobus quoque, et ouibus similiter facies: VI diebus sit cum matrae sua die VII reddes illum mihi. Ex 22.31 Uiri sancti eritis mihi: carnem, quae a bestiis fuerit pregustata, non commedetis, sed proicietis canibus.

150 Ex 23.1 Non suscipies uocem mendacii, nec iunges manum tuam ut pro impio dicas falsum testimonium. Ex 23.2 Non sequeris turbam ad faciendum malum: nec in iudicio, plurimorum adquiesces sententiae, ut a uero deuies. Ex 23.3 Pauperi quoque non misereberis in negotio .

Ex 23.4 Si occurreris boui inimici tui, aut assino erranti, reduces ad eum.

Ex 23.5 Si uideris assinum odientis te iacere sub honore non pertransibis eum, sed leuabis cum eo. Ex 23.6 Non declinabis in iudicio pauperis. Ex 23.7 Mendacium fugiens.

Insontem et iustum non occides: quia aduersator impium est. Ex 23.8 Non accipies munera, quae excecant etiam prudentes et subuertunt

150 p. $118 \mathrm{~W} 156$ p. $6 \mathrm{~A}$

150-151 ut pro impio dicas ] .i. si pecuniam dederit tibi margin $\mathrm{W}$

152 plurimorum ] i. si iniquitatem dixerit interlinear $\mathrm{W}$

153 in negotio ] i. indibbrit interlinear W, for i ndibbrit (? Ir.), cf. DIL, s. dibbrit.

156 pauperis ] i. suaserit malum interlinear $\mathrm{W}$

139 tuo ] deest $\mathrm{W}$ 139-140 occassum ] occasum BO 140 redes ] reddes BOW enim ] deest BW operitur] operietur B $141 \mathrm{nec}]$ non B 143 Diis] dies corr. diis B 144 primitias ] primitiuas BW 145 non tardabis offerre ] offerre non tardabis B 146 bobus] later corr. bouibus O VI diebus] diebus VI W 147 matrae ] matre BOW die ] dies W VII] VIImo O 148 bestiis ] bestis W commedetis] comedetis $\mathrm{W}$ proicietis] proiecietis corr. proicietis A proiecitis B proic[iet]is $\mathrm{O}$ proicitis $\mathrm{W} \mathbf{1 5 0}$ mendacii] mendacis $\mathrm{O}$ nec] non $\mathrm{W} 151$ sequeris ] sequaris W 152 sententiae ] sentententiae W 153 a uero deuies ] declines a uero W non... negotio] in negotio non misereberis $\mathrm{W}$ in negotio] deest $\mathrm{B} \mathbf{1 5 4}$ boui] boi B assino ] asino BOW 155 assinum ] asinum BW asinam O odientis ] odientes $\mathrm{W}$ honore ] honere $\mathrm{B}$ onere $\mathrm{OW} \mathbf{1 5 6}$ eum ] eam $\mathrm{O}$ deest $\mathrm{W}$ declinabis ] declines W 158 aduersator] aduersor BW impium] impius BW [imp]ium O est] deest W 159 excecant] excaecant W etiam... subuertunt] oculos sapientium et W 
160 uerba iustorum.

Ex 23.9 Peregrino molesti non eritis. Scitis enim aduenarum animas quia et ipsi fuistis peregrini in terra egipti.

Ex 23.10 VI annis seminabis terram tuam, et congregabis fruges eius: Ex 23.11 anno autem VII uel dimites eam, requiescere facies, ut commodant pauperes populi tui: et quidquid reliqui fuerit, et dant bestiae agri: ita facies in uinea et in oliueto tuo. Ex 23.12 VI diebus operaberis: VII die cessabis, ut requiescat bos et assinus tuus et refrigeretur filius ancillae tuae et aduena. Ex 23.13 Omnia que dixi uobis custodite. Et per nomen externorum deorum non iurabitis, neque audietur ex ore 170 uestro. Ex 23.14 Tribus uicibus per singulos annos mihi festa celebrabitis. Ex 23.15* Asemorum sollempnitatem custodietis. VII diebus redetis asema sicut precipi tibi in tempore mesis nouorum quando egresus es de egipto: non apparebis in conspectu meo uacuus. Ex 23.16 Et solempnitatem mensis primitiuorum operis tui, quecumque seruaueris 175 in agro: sollempnitatem quoque in exitu anni, quam congregabis omnes

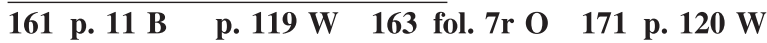

164 dimites eam ] ut in iubeleo interlinear $\mathrm{W}$

170 Tribus uicibus per singulos annos] i. natalis domini et pasca et penticosta interlinear $\mathrm{W}$

172 mesis ] quando frumentum congregatur interlinear $\mathrm{W}$

172 mesis] g interlinear A

172 nouorum ] en neuidteruo interlinear A, 'in the novelties' (Bret.), cf. Stokes, 547; and Dict., 161.

175 sollempnitatem ] sci nopigi interlinear W

160 iustorum ] iustorum commotant W 161-162 Peregrino... egipti] deest $\mathrm{O}$ Peregrino ] peregrinum $\mathrm{W}$ molesti] molestus $\mathrm{W}$ eritis] eris $\mathrm{W} 162$ egipti] aegypti BW $163 \mathrm{VI}$ ] filius [...] quae dixi uobis facite [...] VI O sex W et] deest W eius ] eius tibi O $\mathbf{1 6 4}$ VII. . . requiescere] VII requiescere uel dimittes eam B VII] VIImo $\mathrm{W}$ uel] deest $\mathrm{W}$ dimites ] dimittes $\mathrm{O}$ requiescere ] et requiescere $\mathrm{W}$ commodant] commedant B comedant $\mathrm{OW} \mathbf{1 6 5}$ populi] poppuli $\mathrm{B}$ tui] deest $\mathrm{B}$ quidquid ] quicquid $\mathrm{BW}$ reliqui ] reliquuum $\mathrm{O}$ et dant ] edant $\mathrm{B}$ edent $\mathrm{W}$ ita ] ita ut W 166 in oliueto ] oliueto BOW $\mathbf{1 6 6 - 1 8 3}$ VI diebus operaberis...populi sui] deest O 167 assinus ] asinus W 168 que ] quae BW 169 ex ] in W 171 Asemorum ] azemorum BW sollempnitatem ] solemnitatem BW custodietis ] custodies W redetis ] edetis B edes W $\mathbf{1 7 2}$ asema ] azema BW precipi] precepi B mesis] mensis B messis W egresus ] egressus BW 173 egipto ] aegypto BW uacuus ] uacus W 174 solempnitatem ] sollem $W$ quecumque ] quaecumque B seruaueris ] seruieris $\mathrm{B}$ serueris W 175 sollempnitatem ] solemnitatem B quoque ] quique W quam ] quando BW 
fruges tuas de agro. Ex 23.17 Ter in anno apparebit omne masculinum tuum coram domino deo tuo. Ex 23.18 Non immolabis super fermentum sanguinem uictimae meae, nec remanebit adeps sollempnitatis meae usque in mane. Ex 23.19 Primitias frugum terrae tuae deferes in domum 180 domini dei tui. Non quoques edum in lacte matris suae.

Ex 31.14 Custodite sabatum sanctam enim est uobis: qui polluerit illud, morte morietur; qui fecerit in eo opus peribit anima illius de medio populi sui.

\section{Incipit de leuitico}

185 Lev 5.1 Si peccauerit anima et audierit uocem iurantis et testis fuerit quod aut ipse uidit, aut conscius testis est: nisi indicauerit, portauit iniquitatem suam

Lev 6.1 Locutus est dominus ad moisen, dicens: Lev 6.2 Anima quae peccauerit et contempto domino, negauerit depositum proximo suo

190 quod fidei eius creditum fuerat, uel ui aliquid extorserit aut calumpniam fecerit, Lev 6.3 siue rem perditam inuenerit, et infitias insuper iurauerit, et quodlibet aliud ex pluribus fecerit, in quibus peccare solent homines,

181 p. $121 \mathrm{~W} 186$ p. $7 \mathrm{~A}$

176 Ter ] III sollempni interlinear $\mathrm{W}$

177 fermentum ] i. quam fex non offerebatur in lege tantum interlinear $\mathrm{W}$

178 nec remanebit ] i. dum non tardat mors margin $\mathrm{W}$

178 adeps ] lon interlinear A; Bret. resembling Ir. lón, 'fat, provisions', cf. DIL, 197-8; and Dict., 246.

179 Primitias ] i. preter stipendia margin $\mathrm{W}$

185 testis ] .i. si audierit quisque iurantem falso nec arguerit ut dicitur nisi renuntiaueris reliqua interlinear $\mathrm{W}$

189 depositum ] a interlinear A

190 calumpniam ] i. iurando $\mathrm{W}$

191 infitias ] diblo interlinear A, 'to deny' or 'to soil' (? Bret.), cf. Dict., 137-8.

176 agro ] agro custodies B masculinum ] masculum W 177 tuum ] tuum tuum $\mathrm{W} 178$ meae ] deest $\mathrm{W}$ remanebit] manebit $\mathrm{B}$ sollempnitatis ] solempnitatis $\mathrm{B}$ sollemnitatis $\mathrm{W} \mathbf{1 7 9}$ in ] deest W Primitias ] primitiuas W frugum ] fruguum W 180 quoques ] coques $\mathrm{W}$ edum ] hedum W 181 Custodite sabatum ] sabbatum custodite $\mathrm{W}$ sabatum ] sabatum corr. sabbatum B polluerit] pulluerit W 182 morietur ] moriatur W illius] eius B 183 sui] mei B 184 Incipit de leuitico ] incipit de libro levitico B 186 testis ] deest W $186-\mathbf{1 8 7}$ portauit... suam] iniquitatem suam portabit $\mathrm{W}$ portauit] for portabit; portabit BO 188-201 Locutus dominus... uarios] deest $\mathrm{O}$ moisen ] moysen BW $\mathbf{1 8 9}$ proximo suo] proximi sui B 190 fuerat ] fuerit $W$ ui aliquid ] mali quid $W$ calumpniam ] calumniam $B$ 191 rem perditam ] perditam rem $W$ infitias ] inficians $B$ infitizans $W$ 
Lev 6.4 conuicta delicti, Lev 6.5 redet quae per fraudem uoluit obtinere integra, ex V insuper partem domino cui damnum intullerat. Lev 6.6* Pro peccato autem suo arietem immaculatum.

Lev 7.19 Caro, quae tetigerit aliquid inmundum, non commedetur, sed conburetur igni: qui fuerit mundus non uescetur ea. Lev 7.20 Anima polluta quae ederit de carnibus hostiae pacificorum, quae oblata est domino, peribit de populis suis.

200 Lev 7.24 Adipem cadaueris mortui et eius animalis, quod a bestia captum est, habebitis in ussos uarios.

Lev 7.26 Sanguinem quoque omnis animalis non edetis in cibo, tam de auibus, quam de pecoribus. Lev 7.27 Omnis anima, quae ederit sanguinem, peribit de populis suis. Lev 11.33* In quo horum quiquam intro ceciderit, polluetur. Lev 11.35* Id morticinum: siue clibani, siue scitropes destruentur, et inmundi erunt. Lev 11.36 Fontes uero et cisterne et omnis aquarum congregatio inmunda erit. Qui morticinam eorum tetigerit, polluetur, idem inmundorum animalium.

Lev 12.1 Locutus est dominus ad moisen, dicens: Lev 12.2 Loquere filiis 210 israhel, et dic ad illos: Mulier, si suscepto semine peperit masculum, inmunda erit VII diebus iuxta dies separationis menstruae. Lev 12.3 Et die VIII circumcidetur infantulus: Lev 12.4 ipsa uero XXXIII diebus

\section{3 p. 122 W 202 p. 12 B 204 p. 123 W}

193 conuicta ] i. anima interlinear $\mathrm{W}$

195 immaculatum ] .i. castitatem interlinear $\mathrm{W}$

206 scitropes ] t interlinear A, for *trepediou, 'kitchen utensils with three legs' (Bret.), cf. Stokes, 548; .i. uassa uel bunni interlinear W, (particular pots or bowls?)

208 polluetur] .i. inmundorum animalium nisi lauatur postea interlinear $\mathrm{W}$

193 redet ] reddet omnia B reddet anima W 194 ex ] et BW V] quintam BW damnum ] dampnum $\mathrm{W}$ intullerat] intulerat $\mathrm{B}$ intollerat $\mathrm{W}$ Pro] reddet pro W 195 autem ] deest B immaculatum ] inmaculatum B inmaculatum offerat W 196 tetigerit aliquid ] aliquid titigerit W 198 ederit ] ediderit W 200 mortui] morticini W 201 habebitis] habebis W ussos ] usus B ussus W 202 omnis animalis ] animalis omnis $\mathrm{O}$ edetis] ede[ti]s $\mathrm{O}$ commedetis $\mathrm{W}$ cibo] cibos W 203 pecoribus ] peccoribus B ederit] aederit W 204 suis] meis $\mathrm{O}$ 204-226 In quo horum... interibit] deest $\mathrm{O}$ In quo horum ] morticinum inmundorum animalium in quorum $\mathrm{W}$ quiquam ] quicquam BW 205 Id] id est W morticinum ] morticinam W clibani] clibanus W 206 scitropes ] scitropedes B chitropedes W destruentur ] destruantur W cisterne ] cisternae BW 207 inmunda] mundi W morticinam ] morticinum W 208 idem... animalium] deest W idem] id est B 209 moisen ] moysen BW 212 VIII] VII W circumcidetur ] circumcideretur BW XXXIII] XXXVI BW 
manebit in sanguine purificationis suae. Omne sanctum non tanget, nec ingredietur sanctuarium, donec impleantur dies purgationis eius.

215 Lev 12.5 $\mathrm{Si}$ autem feminam peperit, inmunda erit duabus ebdomadibus iuxta ritum fluxas menstrui, et XL ac VI diebus manebit in sanguine purificationis suae. Lev 12.6*? Postea deffere agnum inmaculatum in olochaustum. Lev 17.10 Homo qui libet de domu israhel et de aduenis qui perigrinantur inter uos, si comederit sanguinem, obfirmabo faciem meam contra animam illius, et disperdam eum de populo suo, Lev 17.11* quia anima carnis in sanguine est. Lev 17.13* Si uenatione aut aucupio caeperis feram, aut auem, quibus uesci licitum est fundas sanguinem eius, et operies eum de terra. Lev 17.14 Anima enim omnis carnis in sanguine est: unde dixi filis israhel: Sanguinem uniuersae carnis non commedetis, quam anima carnis in sanguine est: et quicumque comederit illum interibit.

Lev 17.15* Anima, quae comederit per ignorantiam morticinum, uel captum a bestia, tam de aduenis, quam de indegenis lauabit uestimenta sua et semetipsum aqua, et contaminatus erit usque ad uesperum.

\section{$\overline{214}$ p. 124 W 216 p. 8 A 227 p. 125 W}

214 impleantur ] regnante inpeppe[rit] pentrials in the margin $\mathrm{W}$

217 inmaculatum ] i. innocentiam interlinear $\mathrm{W}$

221 uenatione ] .i. eidguin margin A; from *eidn-guinod, 'bird hunt', cf. Dict., 155.

222 aucupio] ó cuidich interlinear W (Ir.), cf. DIL, s. cuidich.

225 carnis ] .i. quia altrix anime est interlinear W

227 morticinum ] i. qui facit mala opera scripturus in heresim margin W

228 a bestia ] a diabolo interlinear $\mathrm{W}$

228 indegenis ] co interlinear A, for coguenou, 'of the same tribe, akin' (Bret.), cf. Stokes, 549, 550; and Dict., 111, 112; de eodem genere interlinear W

228 lauabit ] i. per iustitiam interlinear $\mathrm{W}$

229 et semetipsum aqua ] i. poenitentia uel doctrina uel baptismum interlinear $\mathrm{W}$

229 contaminatus ].i. separabitur interlinear $\mathrm{W}$

214 purgationis ] purificationis B 215 duabus ] IIabus B 216 fluxas ] fluxus BW 217 deffere ] defferet $B$ deferet $W$ inmaculatum ] immaculatum $B$ innaculatum W 218 olochaustum ] holocaustum BW domu ] domo BW 219 perigrinantur ] peregrinantur BW comederit] commederit B 220 illius] ipsius W 220221 populo... uenatione] interlinear O 221 aut] atque W 222 aucupio] aucupio first ' $u$ ' overhead $\mathrm{W}$ caeperis ] coeperis B caperis $\mathrm{W}$ aut ] uel $\mathrm{W}$ auem ] haec B 223-224 et operies... est] deest $\mathrm{W}$ operies] operias B de] deest B 224 filis ] filiis BW 225 commedetis ] comedetis W quam ] quia W 226 comederit ] commederit B 227 quae ] que W comederit] commederit B per ignorantiam ] later underlined $\mathrm{O}$ deest $\mathrm{W}$ morticinum ] mortinam $\mathrm{W} \quad 228$ tam...quam] deest $\mathrm{W}$ indegenis ] indigenis BO 
230 Lev 18.4* Ego sum dominus deus uester. Lev 18.5 Custodite leges meas adque iudicia mea, quae faciens homo, uiuet in eis. Ego dominus. Lev 18.6* Omnis homo ad proximam sanguinis sui non accidet, ut reueletur turpitudinem eius. Lev 18.7 Turpitudinem patris tui et turpitudinem matris tuae non discoperies, quia mater tua est, non reuelabis turpitudinem eius. Lev 18.8 Turpitudinem uxoris patris tui non discoperies: Turpitudo enim patris tui est.

Lev 18.9 Turpitudinem sororis tuae ex patre siue ex matre, quae domi uel foris genita est, non reuelabis.

Lev 18.10 Turpitudinem filiae filii tui uel nepotis ex filia non reuelabis:

240 quia turpitudo tua est.

Lev 18.11 Turpitudinem filiae uxoris patris tui, quam peperit patri tuo, et soror tua est, non reuelabis.

Lev 18.12 Turpitudinem sororis patris tui non discoperies quia caro patris tui est.

245 Lev 18.13 Turpitudinem sororis matris tuae non reuelabis, eo quod caro sit matris tuae.

Lev 18.14 Turpitudinem patris tui non reuelabis nec accides ad uxorem quae tibi afinitate coniungitur.

Lev 18.15 Turpitudinem nurus tuae non reuelabis, quia uxor filii tui est:

250 nec discoperies ignominiam eius.

Lev 18.16 Turpitudinem uxoris fratris tui non reuelabis, quia turpitudo fratris tui est.

240 p. 126 W 243 fol. 7v O 245 p. 7 B 247 p. 9 A

232 proximam ] .i. feminam interlinear $\mathrm{O}$.i. si deo de[..] genere interlinear $\mathrm{W}$

233 turpitudinem matris] ni dinoe margin $\mathrm{A}$, for $n i \operatorname{dino}(g) e$, 'you shall not make bare' (Bret.), cf. Stokes, 548; and Dict., 267; si degenere eius et si de matre tua ideo genelogiam christi non meruit perseduci interlinear $\mathrm{W}$

242 soror tua ] i. ex patre interlinear W

230 sum ] deest $\mathrm{W} 231$ adque ] atque BOW uiuet] uiuat $\mathrm{W} 232$ Omnis homo ] deest $\mathrm{W}$ proximam ] proxima $\mathrm{W}$ accidet ] accedet $\mathrm{B}$ reueletur] reuelet $\mathrm{BOW}$ 234 discoperies] discooperies BOW 235 discoperies] discooperies BOW 237 quae domi ] quae est in domu W 239 filiae ] filiae tuae uel W nepotis ] nepotes corr. nepotis W 241 uxoris ] uxoris tu W quam ] quae B 243 discoperies ] discooperies BW 245 sororis ] soris W tuae ] tue B 246 sit] deest W tuae ] tuae est W 247248 Turpitudinem. .. coniungitur] deest $\mathrm{W}$ accides ] accedes B uxorem ] uxorem eius B [uxorem] eius O $\mathbf{2 4 8}$ afinitate] adfinitate BO $\mathbf{2 5 0}$ nec] non W discoperies ] discooperies BW 251 tui] deest B $\mathbf{2 5 2}$ fratris ] f/ratris corr. fratris A 
Lev 18.17* Turpitudinem sororis tuae et filie non reuelabis. Filiam filii eius et filiam filiae illius non summes, ut reueles ignominiam eius: quia caro illius sunt, et talis coytus incestus est.

Lev 18.18 Sororem uxoris tuae inplicatum non accipies, nec reuelabis turpitudinem eius adhuc illa uiuente.

Lev 18.19 Ad mulierem quae patitur menstrua non accides, nec reuelabis feditatem eius.

260 Lev 18.20 Cum uxore proximi tui non choibis, nec seminis conmixtione maculaueris.

Lev 18.21 De semine tuo non dabis ut consecretur idolo moloch, nec pollues nomen domini dei tui. Ego dominus.

Lev 18.22 Cum masculo non commisceris coitu femineo, quia abominatio est.

Lev 18.23 Cum omni pecude non coibis, nec maculaueris cum eo.

Mulier nec succumbet cum iumento, nec miscebitur ei, quia scelus est. Lev 18.24 Nec pulluamini in omnibus hiis quibus contaminate sunt uniuersae gentes, quas ego eieciam ante conspectum uestrum.

270 Lev 18.29 Omnis anima, quae fecerit de habominationibus hiis quippiam, peribit de medio populi sui.

258 p. 127 W

255 incestus ] i. scelus interlinear $\mathrm{A}$.i. nefas interlinear $\mathrm{O}$ is cuilech interlinear $\mathrm{W}$, '[it] is sinful, vile', cf. DIL, s. cuilech.

259 feditatem ] b interlinear AW, for *breinter, 'rotten' (Bret.), cf. Stokes, 549.

264 coitu ] c interlinear $\mathrm{W}$

270 Omnis] in captiui [pro]pter mala [o]pera margin $\mathrm{W}$

253 sororis tuae et filie ] uxoris eius W filie ] filiae eius BO 253-254 Filiam... illius] turpitudinem filiae filii eius et filiae filiae eius $O$ Filiam ] et filiam W 254 illius ] ipsius $\mathrm{B}$ summes] sumes $\mathrm{B}$ su[m]mes $\mathrm{O}$ adsumes $\mathrm{W}$ reueles] reuelabis $\mathrm{W}$ 255 coytus ] coitus OW 256 inplicatum ] inplicatam B inpe[1]licatum O inpellicatum illius W 257 adhuc] ad W 258 menstrua ] menstruam B accides] accedes B reuelabis ] reuelabas corr. reuelabis B $\mathbf{2 5 9}$ feditatem ] foeditatem BOW $\mathbf{2 6 0}$ tui] deest $\mathrm{B}$ choibis ] coibis BW cohibis $\mathrm{O}$ nec] ne $\mathrm{BO}$ conmixtione ] commixione BW commixtione O 261 maculaueris ] maculaberis $O 263$ pollues ] pullues $\mathrm{W}$ domini] deest $\mathrm{BO}$ Ego dominus] deest $\mathrm{W} 264$ Cum...commisceris] deest $\mathrm{W}$ commisceris ] comisceris $\mathrm{O}$ femineo ] faeminino $\mathrm{W}$ abominatio ] abhominatio OW 266 pecude] pecore OW coibis ] cohibis $B$ nec ] neque W maculaueris ] maculaberis $\mathrm{O}$ 267-273 Mulier...proximum suum] deest $\mathrm{O}$ nec] non $\mathrm{W}$ cum] deest $\mathrm{W}$ miscebitur] miscetur B 268 pulluamini] polluamini B hiis] his BW contaminate ] contaminatae B $\mathbf{2 6 9}$ uniuersae ] uniuersa W eieciam ] eiciam BW 270 de ] deest $\mathrm{W}$ habominationibus ] abhominationibus $\mathrm{B}$ abhominatio $\mathrm{W}$ hiis ] his BW quippiam ] quipiam B 
Lev 19.11 Non facietis furtum. Nec mentiemini, nec decipiat unus quisque proximum suum.

Lev 19.12 Non periurabis in nomine meo et pollues nomen domini tui.

275 Ego dominus.

Lev 19.13 Non facies calumpniam proximo tuo et non obprimes eum.

Non demoretur merces mercennarii apud te usque mane.

Lev 19.14 Non maledices surdo, nec coram ceco pones offendiculum: sed timebis dominum tuum, quia ego sum dominus.

280 Lev 19.15 Non facies quod iniquum est, nec iniuste iudicabis. Nec consideres persunam pauperis, nec honores uultum potentis. Iuste iudica proximo tuo. Lev 19.16 Non eris criminator et susurro in populis. Non stabis contra sanguine proximi tui. Ego dominus.

Lev 19.17 Non oderis fratrem tuum in corde tuo, sed argues eum placide, 285 ne habeas per illum peccatum.

Lev 19.18 Non queres ultionem, nec inmineris iniuriae ciuium tuorum. Diliges amicum tuum sicut teipsum. Ego dominus. Lev 19.19 Leges meas custodite. Iumenta non facies coire cum alterius generis animantibus. Agrum non seres diuerso semine. Ueste, quae ex duabus texta est coloribus, non indueris. Lev 19.20 Homo, si dormierit cum muliere coitu seminis, quae sit ancella etiam nobilis, et pretio non redempta, nec

274 p. 128 W 281 p. 10 A 284 p. 129 W

277 demoretur ] ni inu interlinear A, for *ni hinu (?, Bret.), cf. Dict., 268.

288 coire ] c interlinear AW

$\mathbf{2 8 8}$ alterius ] i. non coniuges bouem cum asinum interlinear $\mathrm{W}$

272 facietis ] facies B Nec] non W 274 et] ut overhead $\mathrm{O}$ nec W domini] domini dei BW 276 calumpniam ] calumniam BW calum[...] $\mathrm{O}$ et non] nec ui OW 277 demoretur] morabitur $\mathrm{W}$ merces] mercis $\mathrm{W}$ mercennarii] mercennarii tui B mercinari tui $\mathrm{W}$ mane] in mane BOW $278 \mathrm{nec}$ ] non $\mathrm{W}$ ceco] caeco $\mathrm{O}$ 279 dominum ] dominum deum W 280-294 Non facies... sanguine] deest; some material through damage, other undoubtedly through omission O 281 consideres] consideras W persunam ] for personam A honores] honoris $\mathrm{W}$ uultum ] personam W 282 criminator ] creminator W et susurro ] et non cremina eris susurrario W $\mathbf{2 8 3}$ sanguine] sanguinem BW $\mathbf{2 8 4}$ oderis ] oderes corr. oderis B hodies W $\mathbf{2 8 4}$ 285 argues... peccatum] puplice placide argue eum non habeas peccatum per illum $\mathrm{W}$ 286 queres ] queras B ultionem ] uultionem B inmineris ] memineris B memor eris W 287 amicum ] proximum W sicut ] tanquam W 287-288 Leges...custodite] custodite leges meas W $\mathbf{2 8 8}$ alterius ] alteris W 289-290 Ueste... indueris] deest W duabus ] duobus B 290 dormierit] dormiat W 291 ancella ] ancilla BW nobilis ] nubilis $\mathrm{W}$ et] et tamen $\mathrm{W}$ redempta ] redemta $\mathrm{W}$ 
libertate donata: uabulabuntur ambo, et non morientur, quia non fuit libera. Lev 19.21* Pro delicto autem suo offeret domino. Lev 19.26 Non commedetis carnem cum sanguine.

295 Non auguriabemini, nec obseruetis sompnia. Lev 19.27 Nec in rotundum adtendebitis comam nec radatis barbam. Lev 19.28* Et super mortuum non incidetis carnem uestram. Lev $19.31 \mathrm{Nec}$ declinetis ad magos.

$\mathrm{Nec}$ ab ariolis aliquid scisscitami, ut ne pullemini per eos.

Coram cano capite consurge, et honora personam senis: et time deum

300 tuum. Ego dominus. Lev 19.33 Si habitauerit aduena in terra uestra, et moratus fuerit inter uos, ne exprobretis ei: Lev 19.34* sed sit inter uos quasi indegena, et diligetis eum quasi uosmetipsos.

Nolite facere iniquum aliquid in iudicio, in regula, in pondere, in mensura. Lev 19.36* Statera autem iusta et equa sint pondera, iustus modius sit et equus sextarius.

Lev 20.6 Anima, quae declinauerit ad imagos et ad auriolos et fornicata fuerit cum eis, ponam faciem meam contra eam, et interficiam illam de medio populi sui. Lev 20.7* Sanctificamini et esto sancti, quia ego sanctus sum.

\section{3 p. 8 B 295 fol. 8 r O 297 p. 130 W}

292 uabulabuntur ] frec interlinear A, from frega, 'to rip, tear' (? Bret.), cf. Dict., 172.

296 radatis ] res interlinear A, for resit, 'you shave', cf. Dict., 295.

$298 \mathrm{ab}$ ariolis aliquid ] darcenneti:. rā interlinear A, 'prophets, announcers' (Bret.), cf. Dict., 129.

299 cano ] loit interlinear A, 'grey, aged' (Bret.), cf. Dict., 246.

302 indegena ] coguenou interlinear A, 'of the same kindred, akin' (Bret.), cf. Dict., $112-3$.

292 uabulabuntur ] uapulabunt $\mathrm{B}$ uapulantur $\mathrm{W}$ et non morientur] deest $\mathrm{W}$ 293 libera ] liberata W autem ] deest W offeret ] offeret arietem W 293294 Non... sanguine] deest B 294 commedetis ] comeditis W 295 auguriabemini ] auguriabimini $\mathrm{B}$ auguriamini $\mathrm{W}$ nec obseruetis] non obseruabitis $\mathrm{W}$ sompnia ] somnia BO sollempnia W 296 adtendebitis ] attondebitis B atondabitis W 297 incidetis ] incedetis B ad magos] ad imagos W $298 \mathrm{Nec}$ ab] Non ab W ariolis ] auriolis W scisscitami] sciscitamini BOW pullemini] polluemini BOW per] super W 299 deum ] dominum deum $\mathrm{W} \quad 300$ tuum] deest $\mathrm{B}$ 300-302 $\mathrm{Si}$ habitauerit... uosmetipsos] deest $\mathrm{O}$ aduena ] aduenam $\mathrm{W}$ terra uestra ] terram uestram W 301 exprobretis ] expretis B exprobrabitis W 302 indegena ] indigena $\mathrm{B}$ indegina $\mathrm{W}$ diligetis ] diligitis $\mathrm{W}$ 303-304 in mensura... pondera] deest (scribe skipped a line) W 304 equa ] equalia (lia overhead) A aequa B 305 sit... sextarius] et equus sextarius sit $\mathrm{W}$ sit] interlinear $\mathrm{O}$ equus] aequus $\mathrm{B}$ 
310 Lev 20.9* Qui maledixerit patri suo uel matri, morte moriatur: qui patri et matri maledixerit, sanguis eius sit super eum uel in patientia.

Lev 20.10 Si mechatus quis fuerit cum uxore alterius, et adulterium perpetrauerit cum coniuge proximi sui, morte moriatur et mechus et adultera.

315 Lev 20.11 Et qui dormierit cum nouerca sua, et reuelauerit ignominiam patris sui, morte moriatur ambo: sangues eorum super. Lev 20.14 Qui super uxorem filiam, duxerit matrem eius, scelus operatus est: uiuus ardebit cum ea, nec permanebit tantum nefas in medio uestri.

Lev 20.12 Si quis dormierit cum nuro sua, uterque moriantur, quia scelus

320 operati sunt: sangues eorum sit super eos.

Lev 20.15 Qui cum iumento et pecode coierit, morte moriatur: pecus quoque occidite.

Lev 20.16 Mulier, que succumbuerit cuilibet iumento, simul interficite cum eo: sangues eorum sit super eos.

325 Lev 20.17 Qui acciperit sororem suam filiam patris sui, uel filiam matris suae, et uiderit turpitudinem eius, illaque conspexerit fratris sui ignominiam, nefariam rem operati sunt: occidentur in medio populi, eo quod turpitudinem suam mutuo reuelauerint, portabunt iniquitatem

\section{1 p. 131 W 318 p. 11 A 324 p. 132 W}

315 nouerca ] .i. eltroguen interlinear A, 'mother, nurturer', cf. Dict., 157.

319 nuro ] g interlinear A, for *guhid, 'daughter-in-law' (? Bret.), cf. Dict., 172.

327 nefariam rem ] col interlinear A, 'crime, fault' (Bret.), cf. Dict., 113.

328 mutuo reuelauerint] aimseudeticad interlinear A, for a imseudeticad, 'through mutual revelation' (Bret.), cf. Dict., 57-8; and compare Stokes, 550-1.

310 suo uel] et $\mathrm{O}$ suo ] deest $\mathrm{W}$ 310-311 morte... maledixerit] deest (scribe skipped a line) W 311 eum ] ipsum $\mathrm{W}$ uel in patientia ] deest $\mathrm{W}$ patientia ] paenitentia B poenitentia O 312-314 Si mechatur... in medio uestri] deest $\mathrm{O} \quad \mathrm{Si}$ mechatus quis ] si quis moechatus W 313 perpetrauerit ] perpetrauit $B$ coniuge ] uxore $\mathrm{W}$ mechus] moechus $\mathrm{W} 315 \mathrm{Et}$ qui] qui $\mathrm{W}$ nouerca] nouercha $\mathrm{B}$ 316 moriatur ] moriatur corr. moriantur B moriantur OW sangues] sanguis BOW super] sit super eos BOW (sit overhead) O 316-318 Qui...uestri] this sentence follows the next $\mathrm{W} 317$ filiam ] suam $\mathrm{W}$ eius ] deest $\mathrm{W} 319$ nuro] nuru $\mathrm{BO}$ nura W moriantur ] moriatur W 320 sangues ] sanguis BOW 321 pecode ] pecore BO pecude W 322 occidite ] occidete corr. occidite B $\mathbf{3 2 3}$ Mulier, que succumbuerit ] si succubuerit mulier $\mathrm{W}$ que] quae $\mathrm{BO}$ succumbuerit] sucu[.]buerit $\mathrm{O}$ cuilibet iumento ] iumento cuilibet $\mathrm{O}$ simul] similiter $\mathrm{W}$ interficite ] interficientur W 324 cum eo ] deest $\mathrm{W}$ sangues ] sanguis BOW sit ] interlinear O 325-329 Qui acciperit... iniquitatem suam] deest $\mathrm{O}$ Qui] qui autem $\mathrm{B}$ acciperit ] acceperit $\mathrm{B}$ suam ] deest W 326 illaque ] illa quae B 327 medio ] conspectu W populi] populi sui $\mathrm{W} 328$ mutuo] motuo $\mathrm{W}$ portabunt ] et portabunt $\mathrm{W}$ 
suam.

330 Lev 20.18 Qui coierit cum muliere in fluxu menstrui, et reuelauerit turpitudinem eius et ipsa aperuerit fontem sanguinis sui, interficientur ambo in conspectu populi sui.

Lev 20.19 Turpitudinem matertere et amite tuae non discoperies: qui hoc fecerit, ignominiam carnis suae nudabit: portabunt iniquitatem suam ambo.

Lev 20.20 Qui coierit cum uxore patrui uel anculi sui, et reuelauelauelauerit ignominiam cognationis suae, portabunt ambo peccatum suum: absque liberis morientur.

Lev 20.21 Qui duxerit uxorem fratris sui, fecit rem inlicitam: turpitudinem

340 fratris sui reuelauit absque filiis morientur.

Lev 20.23 Nolite ambulare in legitimis nationum, quas ego pulsurus sum ante uos. Omnia enim haec fecerunt, et abominatus sum eos.

Lev 20.27 Uir siue mulier, in quibus pithonicus siue diuinationis fuerit spiritus, morte moriatur: lapidibus obruent eos, sangues eorum sit 345 super illos.

Lev 22.8* Morticinum et captum a bestia non commedent.

337 fol. 8v O 340 p. 133 W 341 p. 9 B

333 matertere ] motrep interlinear A, 'maternal aunt' (Bret.), cf. Dict., 260; .i. soror matris interlinear $\mathrm{W}$

333 amite tuae ] comnidder [uel] nit interlinear A, 'real cousin or niece' (for nith, Bret.), cf. Dict., 115-6, 270; soror patris interlinear W

333 discoperies ] nidinoti interlinear A, for ni dinoti, 'you shall not make bare' (Bret.), cf. Dict., 267.

336 anculi sui] uel frater mater interlinear A

338 liberis ] .i. filios interlinear A

343 pithonicus ] darguid interlinear A, for dorguid, 'druid' (Bret.), cf. Dict., 150.

330 muliere ] mulieri W menstrui] menstruo BOW 331 ipsa] ipse W aperuerit] aperuit BO sui] eius W $\mathbf{3 3 3}$ matertere] materterae B materte[re] O materterae tuae W amite ] amittae BOW discoperies] discooperies BW 334 nudabit] nudauit B 336-337 Qui coierit...peccatum suum] deest (scribe skipped lines) W anculi] aunculi B 336-337 reuelauelauelauerit ] for reuelauerit; reuelauerit B 339-342 Qui duxerit... sum eos] deest $\mathrm{O}$ fecit... inlicitam] rem inlicitam fecit $\mathrm{B}$ rem fecit inlicitam W 340 reuelauit ] reuelabit B morientur ] moriantur B 341 legitimis ] ligitimis W pulsurus ] expulsus W $\mathbf{3 4 2}$ uos ] interlinear B abominatus ] abhominatus W 343 pithonicus ] phitonicus $B$ siue diuinationis] uel diuinationis $W \quad 344$ spiritus ] deest $\mathrm{W}$ moriatur] moriantur W sangues] sanguis BOW 345 illos ] eos BOW 346-360 Morticinum. .. sustullere cogitur] deest $\mathrm{O}$ commedent] comedent $\mathrm{W}$ 
Lev 22.14 Qui commederit de sanctificatis per ignorantiam, addet V partem cum eo quod commedit et dabit sacerdoti.

Lev 22.21 Homo qui obtullerit uictimam pacificorum domino, uel uota soluens, uel sponda offerens, tam de bobus, quam de ouibus, inmaculatum offeret ut acceptabile sit: omnis macula non erit in eo. Lev 22.22* Si cecum, si fractum, sicatricem habens, si papulas aut scapiem, uel inpetiginem: non offeretis ea domino.

Lev 24.15* Homo, qui maledixerit domino sic, portabit peccatum suum;

355 Lev 24.16* et qui blasphemauerit nomen domini, morte moriatur: lapidibus obprimet eum omnis multitudo populi.

Lev 24.18 Qui percuserit animal, reddet uicarium, id est anima pro anima. Lev 24.19 Qui inrogauerit maculam cuilibet ciuium suorum, sicut fecit sic fiet illi: Lev 24.20 fracturam pro fractura, oculum pro oculo, dentem pro dente restituet: qualem inflixerat maculam, talem sustullere cogitur.

Lev 24.21 Qui percusserit iumentum, reddet aliud. Qui percuserit hominem, punietur. Lev 24.22* Equum iudicium sit inter uos, Lev 25.37 pecuniam tuam non dabis fratri tuo ad usuram. Et frugum

352 p. 134 W 353 p. 12 A 363 p. 135 W

352 sicatricem ] cre interlinear A, for creith, 'scab, sore' (Bret.), cf. Dict., 121-2.

352 papulas ] huisicou interlinear A, 'pustule, blister' (Bret.), cf. Dict., 215; bólcha interlinear W, for bolga, 'blisters, boils' (Ir.), cf. DIL, s. bolg.

352 scapiem ] t interlinear A, for trousq/trusc, 'leprous crusts on the skin' (Bret./Ir.), cf. Dict., 309, 324; trusci interlinear W, cf. ibidem.

353 inpetiginem ] inpit $\overline{\mathrm{t}}$ interlinear A, for *impetig tard, 'sudden eruption of the skin' (? Bret.), cf. Dict., 225, 333; reet interlinear W, for rốét, 'a thing' (? Ir.).

355 blasphemauerit nomen domini] i. ut in beelzebub iecit demonem interlinear $\mathrm{W}$ 357 uicarium ] attal interlinear A, 'repayment' (Bret.), cf. Dict., 76.

358 inrogauerit ] admosoi interlinear A, 'he who would soil' (Bret.), cf. Dict., 54.

347 commederit ] comederit W V] quintam BW 348 commedit] comedet W 349 obtullerit ] obtulerit BW 350 uota soluens] soluens uota W sponda] sponte BW de ouibus] ouibus B 351 offeret] offeret domino W omnis ] omne W 352 cecum ] caecum fuerit W sicatricem ] for si sicatricem(?); si cicatricem BW scapiem ] scabiem B $\mathbf{3 5 3}$ inpetiginem] inpitiginem W $\mathbf{3 5 4}$ sic] suo W 355 blasphemauerit ] blasfemauerit W 356 lapidibus ] et lapidibus W obprimet ] opprimet BW omnis multitudo ] multitudo omnis W 357 percuserit ] percusserit W anima ] animam B 359 illi] ei W fractura ] fractura sua B 360 qualem ] talem W inflixerat ] inflixerat B influxerit corr. inflixerit W sustullere ] sustulere B sustinere W cogitur ] cogetur W 361 Qui... aliud] later addition in margin B percusserit ] percuserit B aliud] illud W percuserit] percusserit BOW 362 Equum] aequum BW 363 usuram ] ussuram $\mathrm{W}$ 363-383 Et frugum... quintam partem] deest $\mathrm{O}$ frugum ] fruguum $\mathrm{W}$ 
superhabundantium non exies.

365 Lev 27.1 Locutus est dominus ad moisen, dicens: Lev 27.2 loquere filiis israhel, et dices ad eos: Homo qui uotum fecerit, et sponderit domino animam suam, sub estimatione dabit pretium. Lev 27.3 Si fuerit masculus a XX usque XL annum, dabit $\mathrm{L}$ siglos argenti ad mensuram sanctuari. Lev 27.5 Si autem femina [XXX siclos]. V autem anno usque ad XX, 370 si masculus dabit $\mathrm{XX}$ siglos: femina $\mathrm{XV}$. Lev 27.6 Ab uno mensae usque quinctum annum, pro masculo dabuntur $\mathrm{V}$ sigli: pro femina tres. Lev 27.7 Sexagenarius, et ultra masculus dabit XV siglos: femina $\mathrm{X}$. Lev 27.8 Si paper fuerit, et aestimationem reddere non ualeat, stabit coram sacerdote: et quantum illae aestimauerit, eum posse reddere 375 dabit.

Lev 27.9 Animal autem, quod immolari possit domino, si quis uouerit sanctum erit, Lev 27.10 et inmotari non potest, id est, nec melius malo, nec peius bono: quod si quis inmutauerit, et ipsum quod mutatum est, et illud pro quo mutatum est, consecratum erit domino. Lev 27.11 Animal inmundum, quod immolari domino non potest, si quis uoluerit, adducetur ante sacerdotem: Lev 27.12 qui iudicans utrum bonum an malum sit, statuet pretium. Lev 27.13 Quod dare uoluerit qui offeret addet super aestimationis quintam partem.

\section{6 p. $136 \mathrm{~W}$}

$370 \mathrm{Ab}$ uno mensae ] a natiuitate $\mathrm{W}$

372 Sexagenarius ] .i. sex annus interlinear A

382 an malum ] i interlinear $\mathrm{W}$

364 superhabundantium ] superhabundantiam BW exies] exiges BW 365 moisen ] moysen BW 366 sponderit] spoponderit B 367 estimatione ] aestimatione W pretium ] praetium $\mathrm{W} 368 \mathrm{XX}$ usque $\mathrm{XL}$ ] $\mathrm{XX}$ autem anno usque ad LX W $\mathrm{XL}$ ] XLmum B siglos] siclos BW sanctuari] sanctuarii BW 369 Si autem ] similiter $\mathrm{W}$ femina] foemina $\mathrm{W}$ [XXX siclos]] XXX siclos BW $\mathrm{V}$ autem ] a quindo autem B a V W 370 si masculus] masculus B siglos] siclos BW femina] si foemina $\mathrm{W} \mathrm{XV}$ ] $\mathrm{X} \mathrm{W}$ uno] una deest uno B uno autem $\mathrm{W}$ mensae ] mense BW 371 usque] usque ad BW quinctum ] quintum B VW sigli] sicli BW femina ] faemina W $\mathbf{3 7 2}$ tres] III BW Sexagenarius ] sexgenarius W XV] XXV W siglos ] siclos BW femina] faemina W 373 paper] for pauper; pauper BW aestimationem ] estimationem B ualeat ] ualet BW $\mathbf{3 7 4}$ illae ] ille BW aestimauerit ] estimauerit $B$ eum ] et uiderit eum W 376 immolari] iimolari W possit ] potest W 377 inmotari] inmutari BW est ] deest B 377-378 nec melius... bono] nec peius bono nec melius malo W $\mathbf{3 7 8}$ quis] deest W inmutauerit] immolauerit B 380 immolari] imolari W 381 uoluerit] uouerit W 382 pretium ] praetium W dare ] deest $\mathrm{W}$ qui] is qui $\mathrm{W}$ offeret ] offert BW $\mathbf{3 8 3}$ aestimationis ] estimationis $\mathrm{B}$ aestimationem $\mathrm{W}$ 
Lev 27.14 Homo si uouerit domum suam, et sanctificauerit domino, considerabit eam sacerdos utrum bona an mala sit, et iuxta pretium, quod habeo fuerit constitutum, uenundabitur: Lev 27.15 Sin autem ille qui uouerit, uoluerit redimere eam, dabit $\mathrm{V}$ partem aestimationis supra et habebit domum. Lev 27.16 Quod si agrum possessionis suae uouerit et consegrauerit domino, iuxta mensuram sementis aestimabitur pretium:

390 si XXX modis ordei seritur terra, L siglis uenundetur argenti. Lev 27.17 $\mathrm{Si}$ statim ab uno incipiente iubelei agro, quando ualere potest, redimere tanto aestimabitur. Lev 27.18 Sin autem post aliquandulum temporis, suputauit sacerdos pecuniam iuxta annorum, qui reliqui sunt, numerum usque ad iubeleum et detrahetur ex pretio. Lev 27.19 Quod si uoluerit redimere agrum ille qui uouerat, addet quintam partem aestimate pecuniae et possidebit eum. Lev 27.20 $\mathrm{Si}$ autem noluerit redimere, sed cuilibet fuerit uenundatus, ultra eum qui uouerit redimere non potest.

Lev 27.25 Omnis aestimatio siglo sanctuari punderabitur siglos XX obelos 400 habet.

Lev 27.30 Omnis decimae terrae, siue de frugibus, siue de pomis arborum, domini sunt, et illi sanctificantur. Lev 27.31 $\mathrm{Si}$ quis autem uoluerit

\footnotetext{
384 p. 10 B 388 p. 137 W 389 p. 13 A 399 p. 138 W

391 ualere ] ipn interlinear A, for ith n(imeruam), 'in your estimation' (Bret.), cf. Stokes, 553; also Dict., 228.

399 punderabitur ] pus interlinear A, for puis, 'weight' (Bret.), cf. Dict., 291.

399 obelos ] arga interlinear A, for argant, 'silver' (Bret.), cf. Dict., 72.

400 habet ] ampar interlinear A, from *an-par, 'constitute, represent' (Bret.), cf. Dict., 62; but compare Stokes, 554.
}

385 utrum...et] deest $\mathrm{W}$ pretium ] praetium W 386 habeo] for ab eo; ab eo BOW 387 uoluerit ] uouerit $\mathrm{B}$ redimere ] deest $\mathrm{O} \quad \mathrm{V}$ ] quintam BOW aestimationis ] estimationis B 388 habebit] habebit eam W 388-409 Quod si...monte sinai] deest O 389 consegrauerit ] consecrauerit BW sementis ] seminantis W aestimabitur ] estimabitur B estimauerit W pretium ] praetium W 390 siglis ] siclis BW uenundetur ] uendetur BW 391 ab uno ] anno B ab uno anno W incipiente iubelei] iubelii incipiente uouerit $\mathrm{W}$ iubelei] iubelaei $\mathrm{B}$ agro ] ager $\mathrm{B}$ agrum $\mathrm{W}$ quando ] quanto W 392 redimere ] deest $\mathrm{BW}$ tanto ] tando B aestimabitur ] estimabitur B Sin ] sic B aliquandulum ] aliquantulum B aliquantum W 393 suputauit ] supputabit BW 394 iubeleum ] iubelium W 395 uouerat ] uouerit W quintam ] quinam B 396 aestimate ] estimatae B aestimationis W $\mathrm{Si}$ ] sin W 397 sed ] sed alteri W uouerit] uouerat corr. uouerit A 398 potest ] potuerit W 399 siglo] siclo BW sanctuari] sanctuarii BW punderabitur ] ponderabitur BW siglos ] siclus BW obelos] obolos B 401 Omnis ] omnes W 
redimere decimas suas, addet quintam partem earum. Lev 27.32 Omnium decimarum, boues et oues et caprae, quae sub pastoris uirga transeunt, quidquid decimum uenerit, sanctificabitur domino. Lev 27.33 Non elegitur nec bonum nec malum, nec altero commutabitur, si quis mutauerit: et quod mutatum est et pro quo mutatum est sanctificabitur domino et non redimetur. Lev 27.34 Haec sunt precepta quae mandauit dominus moysi et ad filios israhel in monte sinai. Num 27.7 Ad filios israhel loqueris haec: Num 27.8 Homo cum mortuus fuerit absque filio, ad filiam eius transibit hereditas. Num 27.9 Si filiam non habuerit, habebit successores fratres suos. Num 27.10 Quod si et fratres non habuerit, dabitis hereditatem fratribus patris eius. Num 27.11* Si autem nec patruos habuerit, dabitur hereditas hiis qui ei proximi sunt.

415 Num 35.30* Ad unius testimonium nullus contempnabitur. Num 35.31 Non accipietis pretium hab eo qui reus est sanguis, statim et ipse morietur.

\section{Incipit de libro deuteronomi}

Deut 1.16* Quod iustum est iudicate: siue ciues sit, siue peregrinus. Deut 1.17* Nulla erit distantia personarum inter uos: ita paruum audietis ut 420 magnum, nec accipietis cuiusquam personam, quia dei iudicium est.

Deut 6.4 Audi, israhel: dominus deus tuus, deus unus est. Deut 6.5 Et diliges dominum deum tuum ex toto corde tuo et ex tota anima tua et ex tota fortitudine tua. Deut 6.6 Eruntque uerba, quae ego precipio tibi hodie, in corde tuo: Deut 6.7 et narrabis ea filiis tuis et meditaberis in eis sedens in domo tua, et ambulans in itenere et dormiens atque

\section{1 p. $139 \mathrm{~W} 424$ p. $140 \mathrm{~W} 425$ p. $14 \mathrm{~A} \quad$ p. 5 B \\ 409 israhel ] marginal cross-sign A}

403 quintam ] Vam B 404 boues ] boes B 405 quidquid] quicquid BW decimum uenerit ] decimauerit $\mathrm{W}$ sanctificabitur] sanctificabibitur B elegitur] eligetur B 406 commutabitur ] commotabitur W mutauerit] motauerit W 407 mutatum ] motatum $\mathrm{W}$ est] deest $\mathrm{W}$ mutatum ] motatum $\mathrm{W}$ domino] domino et non redi B 408 precepta] praecepta $\mathrm{W}$ et] deest $\mathrm{W} 409$ Ad... haec] loqueris haec ad filios israhel W $\mathbf{4 1 0}$ filio] filiis $\mathrm{W}$ eius] deest $\mathrm{B} \mathbf{4 1 2}$ suos] eius $\mathrm{W}$ et fratres... habuerit] non habuerit fratres $\mathrm{W} 4 \mathbf{4 1 3}$ eius] deest $\mathrm{O}$ nec] non $\mathrm{W}$ patruos] patruus $\mathrm{O} 414$ hiis ] his BOW ei] deest W 415 contempnabitur] condempnabitur $B$ condemnabitur $O$ Non] nec $\mathrm{BO} 416$ pretium ] praetium $W$ hab eo] ab eo BOW sanguis] sanguinis BOW 417 Incipit de libro deuteronomi] deest OW 418 Quod ] deest $\mathrm{W}$ est ] iudicium $\mathrm{W}$ sit ] deest $\mathrm{W} 4 \mathbf{4 1 9}$ inter uos ] deest W $420 \mathrm{nec}$ ] non $\mathrm{W}$ 421-440 Audi, israhel...timete] deest $\mathrm{O}$ deus tuus] tuus $\mathrm{W}$ 423 ego ] deest $\mathrm{B} 425$ in eis ] deest $\mathrm{W}$ domo] domu B domo corr. domu $\mathrm{W}$ et dormiens] dormiens $\mathrm{W}$ 
consurgens. Deut 6.8 Et ligabis ea quasi signum in manu tua, eruntque et mouebuntur inter oculos tuos, Deut 6.9 et scribe ea in limine hosti domus tuae.

Deut 6.13* Dominum deum tuum timebis et ipsi soli seruies, ac per nomen eius iurabis.

Deut 6.16 Non temptabis dominum deum tuum, sicut temptasti in loco temptationis. Deut 7.26* Nec inferes quipiam ex idolo in domum tuam, ne fias anathema, sicut et illud est. Deut 13.1 Si surrexerit in medio tui profeta, aut qui sumpnium uidisse dicat, et predixerit signum 435 atque portentum, Deut $\mathbf{1 3 . 2}$ et euenerit quod locutus est, et dixerit tibi: Eamus et sequamur deos alienos quos ignoras et seruiamus eis: Deut 13.3 non audietis uerba profetae illius aut sumpniatoris: quia temptat uos dominus deus uester, ut palam fiat utrum diligatis eum an non in toto corde, et in tota anima uestra. Deut 13.4* Dominum deum uestrum sequimini et ipsum timete.

Deut 14.21 Quicquid morticinum est ne uescimini ex eo.

Deut 14.21* Peregrino, qui intra portas tuas est, da ut commedat, uende ei: quia tu populus sanctus domini tui es.

Non quoques aedum in lacte matris suae.

445 Deut 14.22 Decimam partem separabis de cunctis frugibus tuis quae nascuntur in terra per annos singulos, Deut $\mathbf{1 4 . 2 3}$ et comedes in conspectu domini dei tui in loco quem elegerit dominus, ut in eo nomen eius inuocetur.

Deut 16.19* Non accipies personas, nec munera: quia munera excecant ow oculos, et uerba iustorum motant.

\section{7 p. $141 \mathrm{~W}$}

433 anathema ] dilucet interlinear A, 'to deprive of light, to excommunicate' (Bret.), cf. Dict., 142, 247.

426 eruntque ] erunt quae B et erunt W 427 hosti] hostii B hostis W 431 loco] loc B 432 quipiam ] quidpiam B quippiam W 434 profeta ] propheta BW sumpnium ] somnium BW uidisse] uidisse se BW dicat] dicit corr. dicat B 435 portentum ] portendum B 437 profetae ] prophetiae B profetiae W sumpniatoris ] somniatoris BW 439 corde ] cordae B corde uestro W 442-444 Peregrino... suae] deest O commedat ] comedat W $\mathbf{4 4 3}$ domini] domini dei W $\mathbf{4 4 4}$ quoques] coques W aedum ] hedum $\mathrm{W}$ suae] interlinear B 449 Non] nec $O$ excecant] ex[cec]ant aetiam $O \mathbf{4 5 0}$ et uerba iustorum motant] sapientium $O$ 
Deut 16.20* Inste quod iustum est persequeris: ut uiuas.

Deut 17.1 Non imolabis domino deo tuo bouem aut ouem, in quo est W macula, aut quippiam uitii: abominatio est domini dei tui.

Deut 17.6 In ore duorum uel trium testium peribit qui interficietur. Nemo occidatur uno contra se dicente testimonium.

Deut 19.4 Haec ergo erit lex homicidae fugientis, cuius uita seruanda est: qui percuserit proximum sum nesciens, et qui heri et nudustertius nullum contra eum habuisse hodium conprobatur: Deut 19.5 sed habisse sempliciter in siluam cum eo ad ligna excedenda et in successione lignorum securis fugerit manu et ferrum lapsum de manu proprio amicum eius percuserit et occiderit: hic ad unam supradictarum urbium confugiet et uiuet.

Deut 19.11 Si quis autem, hodio habens proximum, insidiatus fuerit uitae eius et surgens percuserit eum et mortuus fuerit et fugerit ad unam de supradictis urbibus, Deut $\mathbf{1 9 . 1 2}$ mitent seniores ciuitatis et arripient eum de loco refugi et tradent eum in manum proximi eius, cuius sanguis effusus est et morietur. Deut 19.13* Nec misereberis eius.

Deut 18.10 Nec inuenietur in te qui lustret filium suum, aut filiam, ducens

per ignem: aut qui ariolus sciscitetur et obseruet somnia aut augoria, ne si tinte maleficus, Deut 18.11 nec incantatur ne pithones consulator, nec diuinos, et querat a mortuis ueritatem. Deut 18.12* Omnia enim haec abominabitur dominus.

Deut 19.15 Non stabit testis unus contra aliquem, quicquid peccati et facinoris fuerit: sed in ore duorum aut trium testium stabit omne 452 p. 142 W 454 fol. 9 r $O$

454 testium ] testium stet omne uerbum in quo W 456-467 Haec ergo... misereberis eius] deest $\mathrm{O}$ ergo ] deest $\mathrm{W}$ homicidae ] homicide $\mathrm{B}$ uita ] uitae $\mathrm{W}$ seruanda ] seruianda W 457 percuserit] percusserit W et qui] qui W nudustertius ] nudiustertius B 458 nullum... habuisse] cum eo nullum habuisse contra eum W hodium ] odium B habisse ] abisse B habuisse corr. habissse W 459 sempliciter ] simpliciter BW in siluam cum eo ] cum eo in siluam W excedenda ] excidenda B cedenda W 460 fugerit] fuerit in $\mathrm{W}$ manu] deest $\mathrm{B}$ manu proprio] manubrio BW 461 percuserit ] percusserit W 462 confugiet ] confugiat W 463 autem... fuerit] insidiatus fuerit proximum suum hodie habens W hodio] odio B proximum ] proximum suum B 464 percuserit] percusserit W 465 mitent ] mittent B mittaent (n overhead) W seniores ] illum senioribus W ciuitatis ] ciuitatis illius W eum ] deest $\mathrm{W} 466$ refugi] refugii $\mathrm{B}$ effugii $\mathrm{W}$ manum] manu W 467 effusus] effussus BW misereberis ] miserebiris W 473 quicquid] quidquid $O$ 
uerbum.

Deut 19.16 $\mathrm{Si}$ steterit testis mendax contra hominem, accusans eum preuaricationis, Deut 19.17 causa stabunt ambo, quorum causa, ante dominum in conspectu sacerdotum et iudicum qui fuerint in diebus illis. Deut 19.18 Cumque diligentissime perscrutantes, inuenerint falsum testem dixisse contra fratrem suum mendatium, reddent ei sicut fratri suo facere cogitauit et auferes malum de medio tui.

Deut 22.5 Non induetur mulier uestae uiri, nec uir utetur ueste feminea: abominabilis est enim aput deum qui facit haec. Deut 22.6 $\mathrm{Si}$ ambulans per uiam, in arbore uel in terra nidum auis inueneris et matrem pullis uel ouis de super incubantem: non tenebis eam cum filiis, Deut 22.7 sed abire patiaris, captos tenens filius: ut bene sit tibi, et longo uiuas tempore. Deut 22.8 Cum edificaueris domum nouum, facies murum tecti per circuitum: ne effundatur sanguis in domo tua et sis reus labente alio, et in preceps ruente.

490 Deut 22.28 Si inuenerit uir puellam uiginem, quam non habet sponsum, et adprehendens concupuerit cum ea et res ad iudicium uenerit: Deut 22.29 dabit qui dormiuit cum ea patri puelle $\mathrm{L}$ siclos argenti, et habebit eam uxorem, quia humiliauit illam: non poterit dimitere eam omnibus

\section{$\overline{476}$ p. 144 W 479 p. 15 A 486 p. 6 B 487 p. 145 W}

479 perscrutantes ] .i. iudices $\mathrm{W}$

481 auferes malum de medio tui] i. si sic facies interlinear $\mathrm{W}$

491 concupuerit ] .i. doguor interlinear A, 'to assault, violate' (Bret.), cf. Dict., 148.

476 accusans ] acusans W 477 preuaricationis ] preuaricatores W causa...causa] stabunt ambo quorum causa est W $\mathbf{4 7 8}$ in conspectu ] interlinear addition adducitur $\mathrm{O}$ 479 diligentissime... inuenerint] inuenerint perscrutantes diligentissime $\mathrm{W}$ falsum ] falsem corr. falsum W $\mathbf{4 8 0}$ mendatium ] mendacium BW 482 uestae ] ueste BOW uiri] uirili OW $\mathbf{4 8 3}$ abominabilis] abhominabilis $O$ est enim aput deum ] enim apud dominum $\mathrm{B}$ enim apud deum est $\mathrm{O}$ aput deum est $\mathrm{W}$ haec] hoc ( $h$ with dot over shoulder) A $\mathbf{4 8 4}$ per uiam ] in via W pullis ] pulli W 485 ouis ] auis BOW incubantem ] incumbantem $B$ incubentem $W$ tenebis ] tinebis $W$ filiis ] filis suis $W$ 486 patiaris ] patieris W captos tenens ] tenens captos W filius ] filios BOW longo ] longuo W 486-487 uiuas tempore ] tempore uiuas W 487-489 Cum... ruente] deest $\mathrm{O}$ domum ] domum tuam $\mathrm{W}$ nouum ] nouam BW $\mathbf{4 8 8}$ effundatur] effundetur $\mathrm{W}$ domo ] domu W 489 et in ] in B preceps] praeceps W 490 uir] quis B uiginem ] for uirginem; uirginem BOW quam ] quae BW sponsum ] sponsam W 491 et ] deest $\mathrm{W}$ adprehendens ] adpraehendens B adpraehendens $\mathrm{O}$ concupuerit ] concubuerit BOW 492 dormiuit] dormierit W puelle] puellae BW 493 quia] qui B illam ] illam et $\mathrm{O}$ dimitere ] interl. extra $\mathrm{t}$ added A dimittere BOW 
diebus uitae suae.

495 Deut 23.19 Non fenerabis fratri tuo ad usuram pecuniam, nec fruges, non quamlibet aliam rem: Deut 23.20* sed alieno. Fratri autem tuo absque usura id quod indiget, commotabis: ut benedicat tibi dominus deus tuus.

Deut 23.21 Cum uoueris uotum domino deo tuo, non tardabis reddere: quia requiret illud dominus deus tuus et si moratus fueris, reputauit tibi in peccatum. Deut 23.22 Si non abueris pulliceri absque peccato eris. Deut 23.23 Quod autem egresum est de labiis tuis, obseruabis, et facies sicut promisisti domino deo tuo, et propria uolunte et ore tuo locutus es.

Deut 24.16 Non occidentur patres pro filiis, neque filii pro patribus, sed unusquisque in peccato suo moriatur. Deut 24.17 Non peruertes iudicium aduenae et popilli, nec auferes pignoris loco uiduae uestimentum.

Deut 25.13 Nec habebis in siclo diuersa pondera, maius et minus: Deut 25.14 nec erit in domo tua modius maior et minor. Deut 25.15 Nam habebis iustum et uerum, et modius equalis et uerus erit tibi: ut multo uiuas tempore super terram, quam dominus deus tuus dederit tibi. Deut

510 25.16* Habominabitur enim dominus qui facit haec.

Deut 27.15 Maledictus homo qui facit sculptile et conflatilem, abomina-

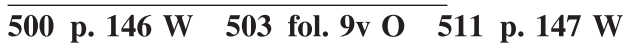

495 ad usuram ] i. ut sit unius modius pro duobus modis $\mathrm{W}$

500 pulliceri] guomonim interlinear A, 'a promise' (?), cf. Dict., 197-8.

$\mathbf{5 0 5}$ auferes] i. a rege $\mathrm{W}$

505 uiduae ] i. trans caput uiduae $\mathrm{W}$

511 conflatilem ] din interlinear A, for *dinouetic, 'make from poured metal' (? Bret.), cf. Dict., 143.

498 reddere ] reddere illud W 499 moratus ] mortuus O reputauit ] for reputabit; reputabit BOW $\mathbf{5 0 0}$ non abueris] nolueris $\mathrm{B}$ non uolueris $\mathrm{W}$ pulliceri] polliceri BW 501 autem ] autem semel W egresum ] egressum BW 502 et propria ] ex probria B uolunte ] for uoluntate; uoluntate BW es] est B 503 neque ] nec W 504 in ] pro W 504-505 iudicium aduenae aduenae iudicium W 505 popilli] pupilli BW nec] non $\mathrm{W}$ pignoris ] pigneris $\mathrm{B}$ uiduae] uidua[.] $\mathrm{O} 506 \mathrm{Nec}$ ] non $\mathrm{W}$ in] deest $\mathrm{B}$ et] nec B 507 nec] ne W domo] domu OW minor] minus pondus W Nam] deest W 508 equalis] aequalis BOW $\mathbf{5 0 9}$ uiuas tempore] tempore uiuas W dederit] dabit B tibi] deest B $\mathbf{5 1 0}$ Habominabitur] abhominabitur BO abominabitur W dominus ] dominus eius $\mathrm{O}$ deus $\mathrm{W}$ haec] insert: incipiunt maledictiones librorum legis W 511 sculptile] for scluptile; scluptile OW conflatilem ] conflatile BW 511-512 abominationem ] abominationem est B abhominationem OW 
tionem domini, opus manuum artificum, exponet illud in abscondito: et respondet omnis populus: Amen.

Deut 27.16 Maledictus qui non honorat patrem suum et matrem: et dicet omnis populus: Amen.

Deut 27.17 Maledictus qui transferet terminos proximi sui: et dicet omnis populus: Amen.

Deut 27.18 Maledictus qui errare facit cecum in itenere: et dicet omnis populus: Amen.

520 Deut 27.19 Maledictus qui peruertit iudicium aduene et popilli et uiduae: et dicet omnis populus: Amen.

Deut 27.21 Maledictus qui dormit cum omni iumento: et dicet omnis populus: Amen.

Deut 27.20 Maledictus qui dormit cum uxore patris sui, et reuelet opermentum lectuli eius: et dicet omnis populus: Amen.

Deut 27.22 Maledictus qui dormit cum sorore sua, filia patris sui siue matris suae: et dicet omnis populus: Amen.

Deut 27.23 Maledictus qui dormit cum socro sua: et dicet omnis populus: Amen.

530 Deut 27.24 Maledictus qui clam percuserit proximum suum: et dicet omnis populus: Amen.

Deut 27.25 Maledictus qui accepit munera, ut percutiat animam sanguinis innocentis: et dicet omnis populus: Amen.

Deut 27.26 Maledictus qui non permanet in sermonibus legis huius, nec eos opere perfecerit: et dicet omnis populus: Amen.

\section{8 p. 16 A 526 p. 148 W}

512 domini ] er interlinear A

512 exponet illud ] et illud ponet W exponet ] et ponet BO 513 respondet ] respondebit W populus ] populus et dicet OW 514 Maledictus ] maledictus homo W matrem ] matrem suam $\mathrm{W}$ dicet] dicat B $\mathbf{5 1 6}$ transferet] transfert $\mathrm{O}$ transferat W terminos ] terminus corr. terminos O $\mathbf{5 1 8}$ cecum ] caecum BW itenere ] itinere W $\mathbf{5 2 0}$ peruertit] uertit OW aduene] aduenae BOW popilli] pupilli BOW 521 dicet] dicat B $\mathbf{5 2 2}$ Maledictus... amen] This sentence follows the next OW omni] interlinear A $\mathbf{5 2 4}$ Maledictus] Meledictus $\mathrm{O}$ sui] deest B reuelet] reuelat BO 525 opermentum ] operimentum BOW 526 siue ] aut W 527 matris ] filia matris W $\mathbf{5 2 8}$ socro] socru BOW dicet] dicat B $\mathbf{5 3 0}$ percuserit] percusserit OW dicet] dicaet B $\mathbf{5 3 2}$ accepit] accipit BOW $\mathbf{5 3 5}$ perfecerit] perfecit B perficiat W 